-Research Note-

\title{
Cytochrome c Upregulation during Capacitation and Spontaneous Acrosome Reaction Determines the Fate of Pig Sperm Cells: Linking Proteome Analysis
}

\author{
Yun-Jung $\mathrm{CHOI}^{1)}$, Sang-Jun UHM ${ }^{1)}$, Sang-Jin SONG ${ }^{1)}$, Hyuk SONG ${ }^{2)}$, Jin-Ki PARK ${ }^{3)}$, \\ Teoan KIM ${ }^{4)}$, Chankyu PARK ${ }^{1)}$ and Jin-Hoi KIM ${ }^{1)}$ \\ 1) Department of Animal Biotechnology, College of Animal Bioscience and Technology, Konkuk University, Seoul 143-701, \\ ${ }^{2)}$ Department of Animal Science, College of Natural Science, Konkuk University, Chungju, Chungbuk 380-701, ${ }^{3)}$ Animal \\ Biotechnology Division, National Livestock Research Institute, RDA, Suwon 441-706 and ${ }^{4)}$ Department of Physiology, \\ Catholic University of Daegu School of Medicine, Daegu 705-718, Korea
}

\begin{abstract}
To identify the mechanisms underlying capacitation, we undertook a high-resolution differential proteomic analysis of pig sperm cells. Two-dimensional gel electrophoresis and subsequent MALDI-TOF mass spectrometry analyses led to identification of 56 differentially expressed proteins. After induction of capacitation in vitro, the wellestablished markers of the capacitation (lactadherin P47, acrosomal protein SP-10 precursor, prohibitin, proteasomes, DJ-1 protein and arylsulfatase-A) and TCA cycle proteins (isocitrate dehydrogenase, malate dehydrogenase and pyruvate dehydrogenase) were identified. During induction, cytochrome c expression via the p53 pathway increased, however apoptotic executors, such as caspase-3, decreased significantly. Therefore, we tested the hypothesis that cytochrome c upregulation in spermatozoa is capable of activating tyrosine phosphorylation for capacitation, rather than apoptosis. Exposure of sperm cells to soluble $\mathrm{Na}_{2} \mathrm{CrO}_{4}[\mathrm{Cr}$ (VI)], which induces cytochrome c upregulation, caused a dose- and time-dependent increase in tyrosine phosphorylation of sperm proteins in non-capacitating medium. In contrast, supplementation of cyclosporin A, which blocks cytochrome c upregulation, inhibited tyrosine phosphorylation of sperm proteins. Furthermore, spermatozoa in capacitation medium or non-capacitation media supplemented with soluble Cr (VI) showed similar levels of capacitation. These findings indicate that differential expression of many of these proteins has previously been unrecognized in sperm cells incubated in capacitation medium also suggest that a gradual increase of cytochrome $\mathrm{c}$ during incubation to induce capacitation determines sperm cell fate, i.e., apoptosis or further development for fertilization.
\end{abstract}

Key words: Capacitation, Cytochrome c upregulation, 2-dimensional gel electrophoresis, Pig, Sperm maturation

(J. Reprod. Dev. 54: 68-83, 2008)

$\mathbf{S}^{\prime}$ permatozoa are terminally differentiated and specialized cells [1]. The deficiencies of major transcriptional and translational activities of sperm are generally known [2] however, recent published evidence shows that sperm are capable of producing major nuclear gene expressions using $55 \mathrm{~S}$ mitochondrial ribosomes during their residence in the female reproductive tract until fertilization [3]. Mature sperm cells are released from the testis with tightly supercoiled, transcriptionally inert DNA [4]. In addition, they do not exhibit progressive motility, but acquire this ability during passage through the epididymis. These processes are referred to as maturation; other maturational changes include completion of nuclear condensation and changes in the expression and distribution of molecules on the cell surface [1]. Therefore, freshly ejaculated sperm cells are incapable of fertilization and must spend some time in a suitable environment in order to capacitate.

Capacitation in all mammals involves shedding of the sperm plasma membrane followed by hyperactivity of the tail, attachment to cumulus cells and adhesion to the zona pellucida for fertilization $[5,6]$. These changes must be achieved by modifications of exist-

Accepted for publication: November 19, 2007

Published online: December 18, 2007

Correspondence: J.-H. Kim (e-mail: jhkim541@konkuk.ac.kr) ing proteins, rather than changes in gene expression, and are modulated by signals from the sperm's environment or may occur spontaneously. As in many mammals, sperm capacitation in pigs requires $\mathrm{Ca}^{2+}$ and bicarbonate $[7,8]$ : the sequence of events for pig sperm capacitation is similar to that of other species. In particular, tyrosine phosphorylation of mouse, human, bull and hamster sperm proteins is closely associated with capacitation [9-11].

Hexavalent chromium [Cr ( VI), $\left.\mathrm{Na}_{2} \mathrm{CrO}_{4}\right]$ is a powerful inducer of cytochrome c release into the cytosol [12]; however, this can be inhibited by treatment with cyclosporin A (CsA) [13]. Although the mechanisms by which $\mathrm{Cr}$ (VI) induces toxicity are still unclear, several reports have suggested that oxidative stress may be a possible pathway $[12,14]$. As part of an investigation into the mechanism of capacitation responses in pig sperm cells, we performed a detailed examination of alternations in protein levels in sperm cells incubated in a capacitation medium. Our study had the following two main aims: (i) to confirm the presence of capacitation-related proteins in pig spermatozoa and (ii) to investigate the relationship between cytochrome $\mathrm{c}$ and the capacitation-promoting signal. We used mature pig sperm cells that had been exposed to capacitating medium (CM) and that exhibited the characteristics of capacitation in order to identify whether or not phenotypic changes were accompanied by compositional changes in sperm head cellu- 
lar compartment and tail hyperactivity. Sperm protein extracts were separated by 2-dimensional (D) gel electrophoresis and analyzed using MALDI-TOF mass spectrometry. Processing of the protein extracts ensured clearly-resolved spots and reproducible analyses.

\section{Materials and Methods}

\section{Antibodies}

Western blotting and immunocytology were performed as described previously [15]. Molecular weight standards were obtained from New England Biolabs (Mississauga, ON, Canada). Monoclonal mouse anti-phosphotyrosine antibody (clone 4G10) was purchased from Upstate Biotechnology (Lake Placid, NY, USA), peroxidase-conjugated goat anti-mouse antibody was purchased from Santa Cruz Biotechnology (Santa Cruz, CA, USA). Membranes were probed with primary antibodies recognizing the following proteins: SOD-Zn/Cu and SOD-Mn [gift from Dr. Seo H-G (Gyeong-Sang National University), rabbit polyclonal antibodies]; peroxiredoxin-5 (Santa Cruz Biotechnology); peroxiredoxin-6 (LabFrontier, Seoul, Korea); proteasome $\alpha / \beta$ (Affiniti Research, Exeter, UK); proteasome Bl-i (Affiniti Research); proteasome B2-i (Affiniti Research); ferritin heavy chain (DAKO, Glostrup, Denmark; H-ferritin); enolase-1 (Santa Cruz Biotechnology); HSP-70 (Calbiochem, La Jolla, CA, USA); iNO and nNOS [gift from Dr Seo. H-G, rabbit polyclonal]; p-p53 (Santa Cruz Biotechnology); Puma (Biotechnology ProSci Incorporated, Poway, CA, UAS); Bax (Santa Cruz Biotechnology); BclxL (Santa Cruz Biotechnology); cytochrome c (Santa Cruz biotechnology); caspase-3 (Calbiochem); caspase-7 (Oncogene, San diego, CA, USA); milk-fat globule (Santa Cruz Biotechnology; MFG); heme-oxygenase-1 (Stressgen; Victoria, BC, Canada; HO1); and GAPDH (Calbiochem) followed by a horseradish peroxidase-conjugated secondary antibody (Jackson Immunoresearch, West Grove, PA, USA). They were then subjected to enhanced chemiluminescence analysis (Amersham, Piscataway, NJ, USA).

\section{Sperm preparation and treatments}

Samples were collected from fertile boars (Berkshire), immediately after washing the semen was diluted in Beltsville TS extender [16] to a concentration of $0.8-1.0 \times 10^{8} \mathrm{cells} / \mathrm{ml}$. The diluted semen was then centrifuged $(270 \mathrm{~g}$ for $10 \mathrm{~min}$ at $22 \mathrm{C})$. The pellet was resuspended at a concentration of $4 \times 10^{7} \mathrm{sperm} / \mathrm{ml}$ in capacitating medium ( $3 \mathrm{~h}$ in $\mathrm{CM})$ to induce capacitation or in noncapacitating medium (NCM) as a non-capacitating negative control $(0 \mathrm{~h}$ in NCM). Sperm morphology was examined shortly after semen collection and sperm motility and acrosomal integrity were estimated at the start of each experiment as described by Petrounkina [17].

\section{Culture media}

The principal culture media were based on Krebs - Ringer bicarbonate [18] as described by Tardif et al. [19]. The capacitating medium (CM) contained $4.8 \mathrm{mM} \mathrm{KCl}, 1.2 \mathrm{mM} \mathrm{KH}_{2} \mathrm{PO}_{4}, 95 \mathrm{mM}$ $\mathrm{NaCl}, 5.56 \mathrm{mM}$ glucose, $25 \mathrm{mM} \mathrm{NaHCO}, 2 \mathrm{mM} \mathrm{CaCl}_{2}, 0.6 \%$ BSA and $1 \mathrm{mM}$ pyruvate (pH 7.4). The non-capacitating medium
(NCM) contained $2.7 \mathrm{mM} \mathrm{KCl}, 1.5 \mathrm{mM} \mathrm{KH} \mathrm{PO}_{4}, 8.1 \mathrm{mM}$ $\mathrm{Na}_{2} \mathrm{HPO}_{4}, 137 \mathrm{mM} \mathrm{NaCl}, 5.55 \mathrm{mM}$ glucose and $1 \mathrm{mM}$ pyruvate ( $\mathrm{pH}$ 7.4). The osmolarity of the NCM and CM were $320 \pm 2.6$ and $269.5 \pm 1.22$ Osm (OSMOMAT 030, Genotec, Berlin, Germany), respectively, and $\mathrm{pH}$ was 7.4 for both. Following addition of media, the sperm cells were incubated at $37 \mathrm{C}$ in a $5 \% \mathrm{CO}_{2}$ humidified atmosphere for up to $3 \mathrm{~h}$.

\section{Flow cytometry analysis}

Fertile boar-derived sperm cells were divided into two samples. The first was diluted and incubated in $\mathrm{CM}$ for $3 \mathrm{~h}$ to induce capacitation, and the second was incubated in NCM for $3 \mathrm{~h}$ or obtained at the beginning of incubation in NCM as a non-capacitating, negative control. Each spermatozoa was incubated for $30 \mathrm{~min}$ at room temperature with PBS containing anti-mouse $\operatorname{IgG}(0.22 \mathrm{mg} / \mathrm{ml}$; Zymaid) in order to block non-specific binding sites, and was then washed 3 times with PBS and centrifuged (1,100 rpm for $10 \mathrm{~min}$ ). Following the appropriate treatment and incubation, sperm suspensions were analyzed using a Flow Cytometer (Beckmam Coulter Altra). Sperm cells were passed through the instrument at approximately $600-1,000$ cells/sec, and data were collected for 20,000 cells (logarithmic scales were used). The cells were excited at 488 $\mathrm{nm}$ using an argon laser; FITC-fluorescence was detected using a $520 \mathrm{~nm}$ band pass filter (FL-1). In addition, capacitated sperm cells were identified using fluorescein-labeled anti-CD46, as described previously [20], and/or were determined by counting 200-300 spermatozoa/sample at $\times 1,000$ magnification after double vital staining with trypan blue Giemsa [21].

\section{Two-D gel electrophoresis}

Two-D gel electrophoresis and spot analysis were performed according to our previous method [22], with slight modifications. Sperm samples $\left(5 \times 10^{8}\right.$ cells $\left./ \mathrm{ml}\right)$ were solubilized in a lysis buffer containing $7 \mathrm{M}$ urea, $2 \mathrm{M}$ thiourea, 4\% (w/v) CHAPS, $40 \mathrm{mM}$ DTT and $1 \%$ pharmalyte $(\mathrm{pH} \mathrm{4-7).} \mathrm{Insoluble} \mathrm{material} \mathrm{was} \mathrm{removed} \mathrm{by}$ centrifugation. IPG strips (17 cm, pH 4-7, Bio-Rad, Hercules, CA) were rehydrated overnight in $300 \mu \mathrm{l}$ of lysate that contained $500 \mu \mathrm{g}$ of protein. The total proteins used in these experiments were quantified using a Bio-Rad Protein Assay Kit (Bio-Rad). Isoelectric focusing was performed using an IPGphor Isoelectric Focusing System (Bio-Rad). The sample was mixed with an appropriate amount of rehydration buffer that contained $8 \mathrm{M}$ urea, 2\% 3-[(3cholamidopropyl) dimethylammonio]-1-propanesulfonic acid (CHAPS), 0.5\% IPG buffer (Bio-Rad), $20 \mathrm{mM}$ dithiothreitol (DTT) and a few grains of bromophenol blue and was applied to $17 \mathrm{~cm}$ Immobiline DryStrips (Bio-Rad) by rehydration overnight in a strip holder. The rehydration conditions were as follow; we selected a linear strip, set the focus temperature at $20 \mathrm{C}$ and then selected 'active $50 \mathrm{~V}$ for $13 \mathrm{~h}$ ' for reswelling. The IE focusing conditions were set as $250 \mathrm{~V}$ for $15 \mathrm{~min}, 250$ to $10,000 \mathrm{~V}$ for $3 \mathrm{~h}$, and focusing was terminated for 70,000 Vh. The gels were equilibrated for 15 min with equilibration buffer I, which contained $50 \mathrm{mM}$ Tris- $\mathrm{HCl}$ (pH 8.8), $6 \mathrm{M}$ urea, 30\% glycerol, $2 \%$ SDS, a few grains of bromophenol blue and $65 \mathrm{mM}$ DTT, and then with equilibration buffer II, which contained $50 \mathrm{mM}$ Tris- $\mathrm{HCl}(\mathrm{pH} 8.8), 6 \mathrm{M}$ urea, $30 \%$ glycerol, $2 \%$ SDS, a few grains of bromophenol blue and $260 \mathrm{mM}$ 
iodoacetamide for $15 \mathrm{~min}$ [23]. The proteins were separated on $7.5-17.5 \%$ polyacrylamide gradient gels, and then Coomassie staining was performed with Coomassie Brilliant Blue G250 according to Sanchez et al. [24].

Target spots, identified using PDQuest, were excised from the gel, destained and digested with bovine trypsin (Roche, Amere, The Netherlands) for identification by MALDI-TOF mass spectrometry. Reactions were terminated with TFA (final concentration: $10 \%$ ) and peptides were concentrated and desalted using ZipTips [( $\mu$-c18), Millipore, Etten-Leur, The Netherlands] and eluted directly onto the MALDI target in a $1 \mu$ saturated solution of $\alpha$-cyano-hydroxycinnamic acid in $50 \%$ acetonitrile. Peptides were analyzed using a Voyager DE-STR MALDI-TOF mass spectrometer (Applied Biosystems, Framingham, MA, USA) in reflection mode at a $20 \mathrm{kV}$ accelerating voltage. Database searches were performed using ProteinProspector (http://propector.UCSF.edu) and PROWL (http://www.proteometrics.com).

\section{Immunofluorescence microscopy}

Immunofluorescence microscopy was performed as described previously [25]. Sperm incubated under capacitating and noncapacitating conditions were air dried onto slides, washed three times with PBS, permeabilized with methanol, washed again with PBS and then blocked with $10 \%$ normal goat serum in PBS. Incubations were then carried out with antibodies [acrosomal tyrosine kinase c-Yes (1:50), HO-1 (1:50), SOD-Zn/Cu (1:100), SOD-Mn (1:100), Proteasome $\alpha / \beta$ (1:50), Proteasome B1-i (1:50), Proteasome B2-i (1:50), H-ferritin (1:50), MFG (1:50) and Enolase-1 (1:50)] diluted in PBS and with 1\% normal goat serum for $30 \mathrm{~min}$. The slides were then washed and incubated for $30 \mathrm{~min}$ with FITCconjugated $\mathrm{F}(\mathrm{ab}$ ')2 fragments of donkey anti-mouse IgG (1:200) or donkey anti-rabbit IgG (1:200; Jackson Immuno Research, Baltimore, PA, USA) in PBS and with 1\% normal goat serum. After washing three times, the sperm cells were stained using PI. The slides were then washed with PBS and mounted with Slow-Fade Light (Molecular Probes, Eugene, OR, USA). Sperm were observed using differential interference contrast and epifluorescence microscopy using a microscope (Axiophot, Carl Zeiss, Yena, Germany).

\section{Statiscal analysis}

All experimental data are presented as means \pm SD. Each experiment was performed at least three times and was subjected to statistical analysis. Representative exprements are presented in the figures. For statistical analysis, one-way analysis of variance (ANOVA) was performed to determine whether there were differences among the groups $(\mathrm{P}<0.05)$, and Fisher's post-test was performed to determine significance between pairs of groups. A Pvalue below 0.05 was considered significant. Statistical tests were performed using StatView version 5.0 (SAS Institute, Cary, NC, USA).
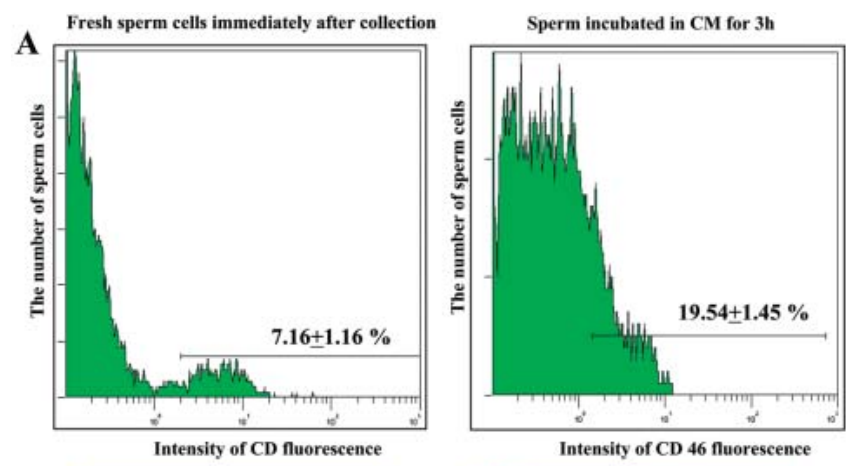

B
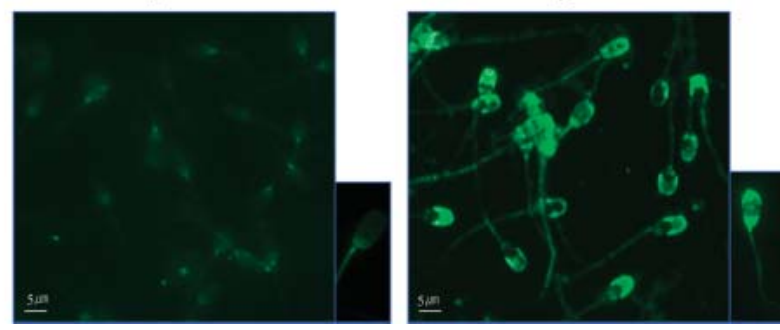

Fig. 1. Capacitation analysis of pig sperm cells with anti-CD46 antibody using flow cytometry and indirect immunolocalization by immunohistochemistry. Control samples were obtained from sperm cells washed with NCM after collection, and capacitated spermatozoa were incubated in $\mathrm{CM}$ for $3 \mathrm{~h}$ and then fised in permeabilizing conditions. A) Flow cytometry analysis. Uncapacitated (left) and capacitated (right) spermatozoa reacted with anti-CD46 polyclonal antibody. The $\mathrm{X}$ and $\mathrm{Y}$ axes indicated intensity of DN 46 fluorescence and the number of sperm cells, respectively. B) Indirect immunolocalization of CD46 in non-capacitated (left) and capacitated (right) pig sperm cells. Localization of CD46 was determined using a polyclonal primary antibody, and a secondary goat anti-rabbit IgG conjugated to fluorescein, and visualized using UV illumination. Magnification was $\times 400$.

\section{Results}

Induction of capacitation and normalization of variation in 2-D gels

Fertile boar-derived sperm cells were divided into two samples; the first was diluted in CM to induce capacitation, and the second was resuspended in NCM as a non-capacitating, negative control. Three hours following incubation in CM, $19.54 \pm 1.45 \%(n=6)$ of sperm cells demonstrated intense reactivity with the anti-CD46 antibody, whereas sperm cells at the beginning of incubation in $\operatorname{NCM}(7.16 \pm 1.16 \%, \mathrm{n}=6)$ and/or sperm cells incubated for $3 \mathrm{~h}$ in NCM $(12.02 \pm 3.44 \%, n=6)$ exhibited only slight reactivity (Fig. $1 \mathrm{~A}$ and $5 \mathrm{~A}$ ), indicating that sperm cells incubated in $\mathrm{CM}$ for $3 \mathrm{~h}$ are just about to undergo capacitation. Therefore, we selected sperm cells incubated for $3 \mathrm{~h}$ in $\mathrm{CM}$ for investigation of the mechanisms underlying capacitation.

To assess the reproducibility of the Coomassie brilliant blue staining, pig sperm proteins were extracted before and after induction of capacitation, and each sample was run on a separate 2-D gel. On 2-D gels in pI region 4-7, approximately 680 protein spots were consistently observed in all samples (Fig. 2A). Of these proteins, 
A Uncapacitated sperm cell proteins

\section{B Capacitated sperm cell proteins}
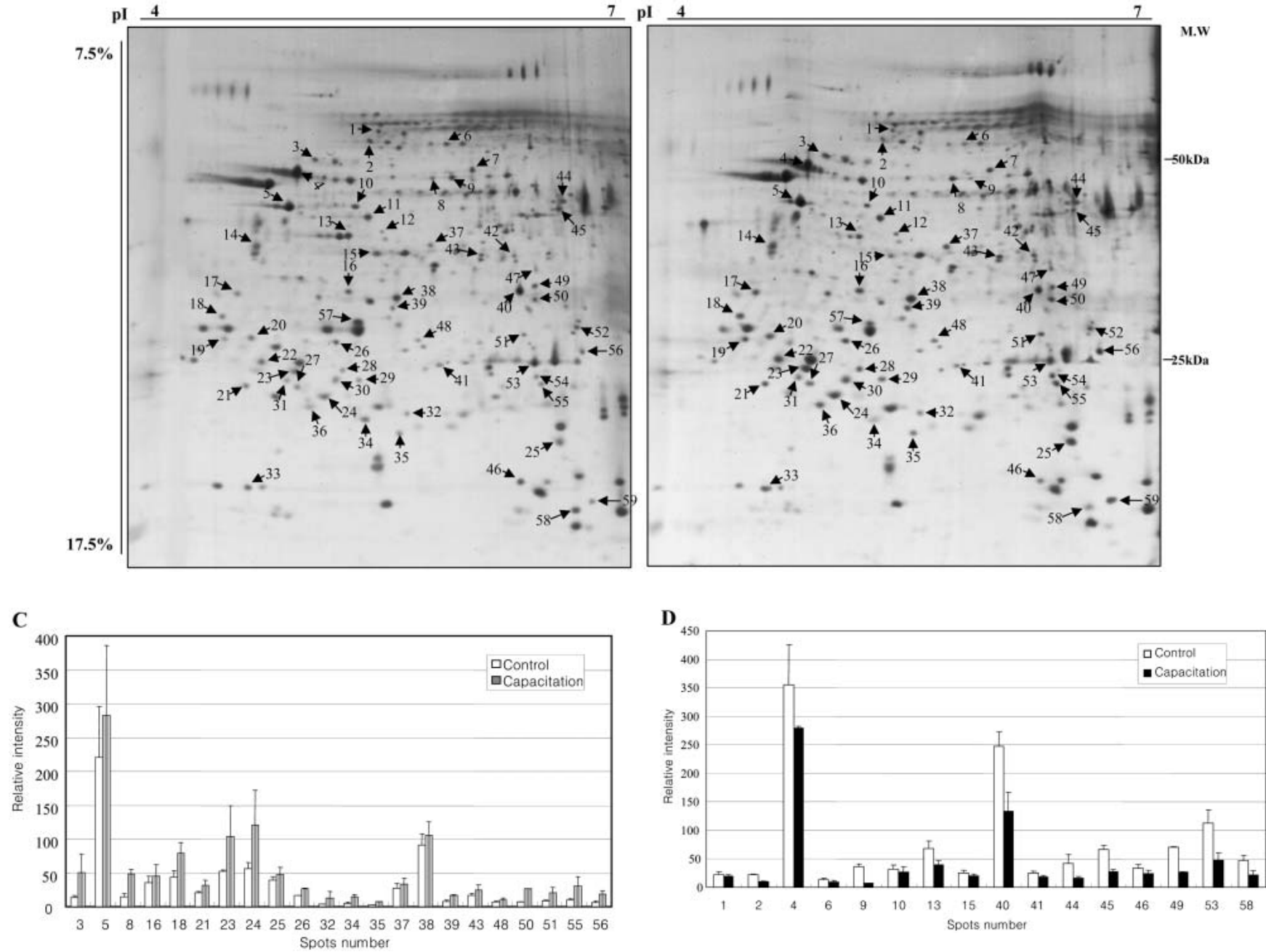

Fig. 2. Two-D gel electrophoresis of non-capacitated and capacitated sperm cells. Total protein was separated by isoelectric focusing in the first dimension, followed by SDS-PAGE gel. A, B) The numbers indicate protein spots that changed in abundance after capacitation induction. C, D) Comparison of the intensity of each spot. The right panel shows the spots that were upregulated, and the left panel shows the spots that were downregulated after capacitation induction. All experimental data are presented as means \pm SD. Each experiment was performed at least three times and subjected to statistical analysis. All increased expression was statistically significant $(\mathrm{P}<0.05)$.

56 spots showed appreciable differences in protein amounts between control (uncapacitated sperm cells) and capacitationinduced spermatozoa. In addition, there were almost no differences in protein expression between fresh spermatozoa (selected by a swim-up method) and spermoatozoa incubated in a non-capacitation medium for $3 \mathrm{~h}$ (data not shown). Fig. $2 \mathrm{~B}$ and sFig. 1 show the positions of the identified proteins and intensities of 56 differentially expressed protein spots. These spots were selected because they were common to all the gels and were either upregulated in sperm cells incubated under capacitating conditions or overexpressed in non-capacitated cells. The highest sequence coverage was obtained from spots 1,4 and 26 (>50\%) by analyzing with ProteinProspector and spots 1 and $26(>50 \%)$ by PROWL. Although G1/S-specific cyclin D3 for spot 34 had a coverage of $11 \%$, this protein corresponded to four peptides and high confi- dence. Additionally, we identified 3 protein spots (spots 7, 11 and 52) that showed a similar expression level between non-capacitated and capacitated sperm cells, indicating that they could be used as an internal control to overcome variability in the 2-D gels. Thus, it was determined that variations in Coomassie brilliant blue staining were very small and would not have a significant adverse affect on the results.

\section{Differentially-expressed proteins during hyperactivity and/or} capacitation of sperm cells

Two sets of capacitated and uncapacitated coomassie stained sample images were analyzed with the PDQuest software. Two-D PAGE and subsequent MALDI-TOF mass spectrometry analyses led to identification of 59 protein spots that appeared in every gel, representing 56 proteins that responded to induction of capacitation 
Table 1. MALDI-TOF analysis of sperm polypeptides identified by 2-D gel

\begin{tabular}{|c|c|c|c|}
\hline $\begin{array}{l}\text { Spot } \\
\text { No. }\end{array}$ & Protein (Mr) & $\begin{array}{l}\% \\
\text { co. }\end{array}$ & $\begin{array}{l}\text { Position of the amino acids of the tryptic peptides } \\
\text { in the protein sequence }\end{array}$ \\
\hline \multicolumn{4}{|c|}{ Proteins known to be involved in the acrosome reaction in other species } \\
\hline 3 & Arylsulfatase A precursor (53776.5) & 16 & $58-72,114-122,123-142,206-213,302-310$ \\
\hline 23 & Acrosomal protein SP-10 precursor (28156.7) & 33 & $205-220,221-227,251-257,258-264$ \\
\hline 24 & Acrosomal protein SP-10 precursor (28156.7) & 31 & $205-220,221-227,251-257,258-264,258-265$ \\
\hline 25 & Acrosomal protein SP-10 precursor (28156.7) & 29 & $205-220,221-227, \mathbf{2 5 1}-\mathbf{2 5 7}, 258-265$ \\
\hline 45 & Lactadherin (45725) & 44 & $\begin{array}{l}132-145,146-155,203-214,215-228,229-236,242-259,267-275 \\
320-330,321-330,331-342,343-356, \mathbf{3 7 8}-\mathbf{3 8 7}, 391-399\end{array}$ \\
\hline 48 & Prohibitin (29804.2) & 43 & $\begin{array}{l}12-35,36-41,84-93,94-105,106-117,118-128,134-143,187-195, \\
220-239,240-253\end{array}$ \\
\hline 58 & DJ-1 Protein (19891.2) & 20 & $\mathbf{6 - 1 2}, 13-27,49-63,123-130,149-156$ \\
\hline \multicolumn{4}{|c|}{ Stress-related proteins } \\
\hline 4 & Tubulin alpha-2 chain (49959.8) & 50 & $\begin{array}{l}65-79,85-96,97-105,106-112,113-121,216-229,230-243,265-280, \\
\mathbf{3 1 2}-\mathbf{3 2 0}, 340-352,353-370,394-401\end{array}$ \\
\hline 7 & T-complex protein 1, alpha (60340.9) & 15 & $19-33,112-122,248-264,434-444,469-480,516-526$ \\
\hline 8 & T-complex protein 1, epsilon (59671.4) & 22 & $133-142,324-340,382-388,401-410$ \\
\hline 9 & T-complex protein 1, epsilon (59671.4) & 48 & $\begin{array}{l}90-96,133-142,177-183,233-241,248-261,324-340,382-388, \\
393-400,401-410, \mathbf{4 4 0}-\mathbf{4 4 9}, 484-496,503-513,514-525,515-525\end{array}$ \\
\hline 13 & Actin (41737.0) & 43 & 19-28, 29-39, 40-50, 96-113, 197-206, 239-254, 292-312, 313-326 \\
\hline 39 & F-actin capping protein $(33741.5)$ & 41 & $\mathbf{1 - 1 4}, 15-23,58-66, \mathbf{7 9 - 9 2}, 95-108,96-108,182-195,226-235,238-244$ \\
\hline 40 & F-actin capping protein (33741.5) & 36 & $\begin{array}{l}44-52,87-95,108-121,124-137,125-137,175-188,198-210,211-224, \\
245-254,255-264,289-297\end{array}$ \\
\hline \multicolumn{4}{|c|}{ Glycolysis/Citric acid cycle-related proteins } \\
\hline 2 & Vacuolar ATP synthase catalytic subunit A (68268.4) & 35 & $\begin{array}{l}45-56,121-129,203-212,221-232,266-280,309-323,354-359 \\
365-381,382-388,514-530,517-530,572-580\end{array}$ \\
\hline 5 & ATP synthase beta chain $(56283.8)$ & 41 & $\begin{array}{l}\text { 95-109, 144-155, 213-225, 226-239, 242-259, 265-279, 282-294, } \\
311-324,325-345, \mathbf{4 0 7}-\mathbf{4 2 2}, 463-480\end{array}$ \\
\hline 38 & Pyruvate dehydrogenase E1 component (39219.6) & 26 & $37-49, \mathbf{3 7}-\mathbf{5 2}, 53-68, \mathbf{3 0 9}-\mathbf{3 2 4}, \mathbf{3 2 5}-\mathbf{3 3 6}$ \\
\hline 43 & Isocitrate dehydrogenase (39592.0) & 24 & $101-115,179-188,300-316,317-326,317-336$ \\
\hline 50 & Malate dehydrogenase (36454.4) & 28 & $67-79, \mathbf{8 0}-\mathbf{9 2}, 150-157,221-230,249-255,299-310$ \\
\hline \multicolumn{4}{|c|}{ Antioxidant-related proteins } \\
\hline 32 & Ferritin heavy chain (21044.8) & 25 & 11-23(pyroGlu), 55-64, 81-87 \\
\hline 35 & Glutathione S-transferase Mu 5 (26635.1) & 25 & $5-14,22-34,36-46,73-81,87-97,100-111,140-147,156-171$ \\
\hline 41 & Peroxiredoxin $6(24818.7)$ & 14 & $25-41,42-53,54-63,145-155$ \\
\hline 44 & Alpha enolase & 36 & $10-15,184-193,240-253,336-343,407-412$ \\
\hline 46 & Superoxide dismutase [Cu-Zn] (15760.6) & 25 & $10-23,27-35,79-90, \mathbf{1 1 5}-\mathbf{1 2 7}$ \\
\hline \multicolumn{4}{|c|}{ Proteasome isoform proteins } \\
\hline 21 & Proteasome subunit beta type 6 precursor (25357.9) & 23 & $54-63,68-74,75-79, \mathbf{1 1 9}-\mathbf{1 2 3}, 210-220,221-230$ \\
\hline 26 & Proteasome subunit alpha type 3 (28405.4) & 52 & $\begin{array}{l}1-20,21-29,30-41,42-52,58-66,73-86,101-110,197-206,197-208, \\
223-230,231-238\end{array}$ \\
\hline 52 & Proteasome subunit alpha type 1(29546.7) & 35 & $4-18,52-61,63-82, \mathbf{8 3}-\mathbf{8 9}, 97-107,175-189$ \\
\hline 56 & Proteasome subunit alpha type 6 (27399.6) & 22 & $12-21,22-30,31-43, \mathbf{7 2}-\mathbf{8 8}, 105-116$ \\
\hline \multicolumn{4}{|c|}{ Phosphorylation-related proteins } \\
\hline 1 & Stress-70 protein $(73528.7)$ & 50 & $\begin{array}{l}127-135,147-159,188-202,207-218,266-284,378-391,395-405, \\
499-513,568-574, \mathbf{6 3 5}-\mathbf{6 5 3}\end{array}$ \\
\hline 10 & cAMP-dependent protein kinase (42981.9) & 18 & 74-91, 97-114, 134-145, 232-240, 252-263, 264-280 \\
\hline 11 & $\begin{array}{l}\text { Ubiquinol-cytochrome c reductase complex core protein } \\
(52619.1)\end{array}$ & 28 & $\begin{array}{l}103-111,112-126,127-134,270-276,416-422,423-432,424-432, \\
471-479,473-479\end{array}$ \\
\hline 18 & Inositol-1(or 4)-monophosphatase (30055.8) & 19 & $60-78,117-129,182-191,249-256,265-273$ \\
\hline 35 & Glutathione S-transferase Mu 5 (26635.1) & 25 & $5-14,22-34,36-46,73-81,87-97,100-111,140-147,156-171$ \\
\hline 38 & Pyruvate dehydrogenase E1 component (39219.6) & 26 & $\mathbf{3 7}-\mathbf{4 9}, 37-52,53-68, \mathbf{3 0 9}-\mathbf{3 2 4}, \mathbf{3 2 5}-\mathbf{3 3 6}$ \\
\hline 39 & F-actin capping protein $(33741.5)$ & 41 & $\mathbf{1 - 1 4}, 15-23,58-66, \mathbf{7 9 - 9 2}, 95-108,96-108,182-195,226-235,238-244$ \\
\hline 40 & F-actin capping protein $(33741.5)$ & 36 & $\begin{array}{l}44-52,87-95,108-121,124-137,125-137,175-188, \mathbf{1 9 8}-\mathbf{2 1 0}, 211-224, \\
245-254,255-264,289-297\end{array}$ \\
\hline \multicolumn{4}{|c|}{ Cell cycle-regulated proteins } \\
\hline 34 & G1/S-specific cyclin D3 (32434.0) & 11 & $42-50,73-87,168-179,270-293$ \\
\hline 37 & G1/S-specific cyclin E1(45586.9) & 16 & $83-99,88-99,116-129,162-171$ \\
\hline \multicolumn{4}{|c|}{ Others } \\
\hline 6 & Serum albumin precursor (69293.9) & 48 & $\begin{array}{l}35-44,161-167,168-183,267-280,360-371,421-433,437-451, \\
469-482,508-523,529-544,581-597\end{array}$ \\
\hline 15 & Tetratricopeptide repeat protein 14 (49771.0) & 16 & $23-32,125-131,322-331,427-435$ \\
\hline
\end{tabular}

Peptides were analyzed by PDquest. Bold peptide numbers indicate an oxidized methionine, respectively.

(Table 1). In most cases, the results of experimental $\mathrm{pI}$ and $\mathrm{Mr}$ of the proteins were in agreement with their theoretical values, which were determined using EXPASY. In sperm cells incubated under capacitating conditions, , 22 of the 56 differentially expressed pretein spots were present at higher levels [a 1.2-fold (spots 25, 37 and 38 ) to 3.9 -fold (spot 50) increase] and 16 of the spots were present 
at lower levels [1.2-fold (spots 1 and 10) to 4.9-fold (spot 9) decrease] when compared to with control, non-capacitated sperm cells.

Table 1 summarizes the main properties of the 56 proteins differentially regulated during the capacitation process in pig sperm cells. They were classified into eight groups based on previous functional studies: (1) proteins known to be involved in capacitation and the acrosome reaction in other species [lactadherin P47, arylsulfatase A (As-A), acrosomal protein SP-10 precursor, DJ-1 and prohibitin]; (2) stress-related proteins (CCT or TCP, also called TRiC, TCP- $1 \alpha, \beta, \varepsilon, \mathrm{F}$-actin capping protein beta, alpha-tubulin 2 and beta-actin); (3) citric acid cycle-related proteins [isocitrate dehydrogenase (IDH), malate dehydrogenase (MDH), $\beta$-subunit of ATP synthase, V-ATP subunit 1 and pyruvate dehydrogenase]; (4) antioxidant-related proteins (glutathione s-transferase $\mathrm{Mu} 5, \mathrm{Cu} / \mathrm{Zn}$ SOD, peroxiredoxin 6 and H-ferritin); (5) proteasome isoform proteins (alpha type 1, alpha type 3, alpha type 6 and beta type 6 precursor); (6) tyrosine phosphorylation-regulated proteins (cAMP-dependent protein kinase type-1 alpha regulatory subunit, inositol-1-monophosphatase, ubiquinol cytochrome c reductase and HSP 70); (7) cell cycle-regulated proteins (cyclin E1 and cyclin D3) and (8) others (Tetratricopeptide repeat protein 14 and serum albumin precursor).

\section{Verification of differentially-expressed proteins in non- capacitated and capacitated sperm cells}

To determine which proteins were differentially regulated before and after induction of capacitation ( $0 \mathrm{~h}$ in $\mathrm{NCM}$ and $3 \mathrm{~h}$ in $\mathrm{CM})$, proteins were excised from a 2-D gel and digested with trypsin. Masses were measured by MALDI-TOF-MS, and the spectrum obtained was compared with MS databases. Representative data is shown in Table 1. Next, we compared protein levels using 2-D gel and Western blot analysis (Fig. 3A) and determined that the patterns were similar, with the exception of the proteasome $\alpha / \beta$-type subunits. In non-capacitated cells, the levels of the proteasome $\alpha$ / $\beta$-type subunits ( 25 to $30 \mathrm{kDa}$ ) and $\beta$ 1i subunit ( $36 \mathrm{kDa}$ ), enolase, aldose reductase, $\mathrm{Cu}-\mathrm{Zn}$ SOD, HSP 70 and peroxiredoxin-6, were significantly decreased. On the other hand in sperm cells incubated under capacitating conditions, the 29 and $30 \mathrm{kDa}$ subunit of proteasome $\beta 2 \mathrm{i}$ and the $30 \mathrm{kDaH}$-ferritin were significantly increased compared with the non-capacitated sperm cells.

\section{Localization of differentially-expressed proteins in sperm cells}

To verify the presence of differentially-expressed proteins in capacitated sperm cells and determine if localization changed following incubation under capacitating conditions, pig sperm cells were incubated in $\mathrm{CM}$ for $3 \mathrm{~h}$ and then immunostained. Antibodies against $\mathrm{C}$-yes, $\mathrm{HO}-1$, proteasome $\beta$ - $2 \mathrm{i}, \alpha / \beta, \beta$-1i-subunit, enolase, $\mathrm{H}$-ferritin, MFG, Mn-SOD and $\mathrm{Cu} / \mathrm{Zn}$-SOD were used (Fig. $3 \mathrm{C}$ ). Using anti-CD46 antibody, the percentage of capacitated sperm was $19.54 \pm 1.54$ ( $n=6$; Fig. 1$)$. Immunofluorescence experiments using antibodies against $\mathrm{C}$-yes, $\mathrm{HO}-1$, proteasome $\alpha / \beta$, proteasome $\beta-2 \mathrm{i}$ and MFG demonstrated that these proteins were localized in the acrosomal regions of sperm incubated under non-capacitating conditions (Fig. 3C). No signal was detected when a control antibody was used or when the primary antibody was omitted (data not shown). H-ferritin, Mn-SOD and CU/Zn-SOD were localized in both the acrosome region and the principal piece of the sperm flagella. After induction of capacitation, these proteins disappeared from the acrosome region, but continued to exhibit strong signals in the principal piece of the sperm flagella. In contrast, proteasome $\beta$ li was localized in the equatorial segment, and no change in localization was observed in acrosome-reacted samples. The intensity of enolase-I staining in the tail changed with capacitation, with $90 \%$ of the spermatozoa losing tail staining by $3 \mathrm{~h}$ after induction of capacitation. These results indicate that SOD and enolase-I exhibit extra mitochondrial localization in the pig spermatozoa and that $\mathrm{Mn}$ - and $\mathrm{CuZn-SOD}$ were present in both the acrosome and principal piece of the sperm flagellum.

Based on our proteomic analysis data, we found some interesting up- and downregulated proteins that are involved in antioxidation, such as Ferritin (spot 32), Peroxiredoxin (spot 41), Enolase (spot 44) and Superoxide dismutase (spot 46). In addition, downregulation of these proteins is involved in regulation of apoptosis via mitochondiral cytochrome c expression/release [26-29]. We, therefore, postulated that cytochrome $\mathrm{c}$ might be a major regulator of the capacitation mechanism or may be involved in regulation in some manner. To identify the role of cytochrome $\mathrm{c}$ in this regard, we performed another experiment to identify the cytochrome c protein level in both capacitated and uncapacited sperm cells, although cytochrome $\mathrm{c}$ is not listed in Table 1. As a consequence, we found that the cytochrome c protein level was significantly increased in the capacitated sperm cells (Fig. 3D). Therefore, we wondered 'what is relationship between cytochrome c and capacitation' and performed a functional study of cytochrome $\mathrm{c}$ in capacitation.

\section{Cytochrome c upregulation determines the fate of sperm cells}

In order to evaluate the impact of cytochrome $\mathrm{c}$ upregulation on capacitation, $\mathrm{Cr}(\mathrm{VI})$ was added to $\mathrm{NCM}$ at concentrations between 1 and $50 \mu \mathrm{M}$ (below the threshold of $\mathrm{Cr}(\mathrm{VI})$ toxicity for cells, data not shown). Time-dependent induction of cytochrome $\mathrm{c}$ by $\mathrm{Cr}(\mathrm{VI})$ was demonstrated, as was increased tyrosine phosphorylation, which is required for acrosome reaction signaling (Fig. 4). Tyrosine phosphorylation of the 28 and $47 \mathrm{kDa}$ proteins increased significantly soon after addition of $\mathrm{Cr}(\mathrm{VI})$ to NCM, and there was a marked increase in capacitation. Spontaneous capacitation was rarely observed in sperm cells that were cultured for $0 \mathrm{~h}$ in NCM alone. However, addition of cyclosporin A, which blocks cytochrome c release into the cytosol, inhibited tyrosine phosphorylation of sperm proteins, indicating that cytochrome $\mathrm{c}$ mediates these activities. Additionally, phosphorylation of the 18 $\mathrm{kDa}$ protein increased in sperm cells cultured in NCM and CM, regardless of alternations in cytochrome c expression.

To examine the relationship between cytochrome-c upregulation and capacitation, a total of 5 aliquots of washed sperm suspensions $\left(0.8-1.0 \times 10^{6} \mathrm{ml}^{-1}\right)$ were prepered, corresponding to the untreated control and 4 different treatments [NCM, CM, NCM+Cr(VI), $\mathrm{NCM}+\mathrm{Cr}(\mathrm{VI})+\mathrm{CsA}]$. The proportion of live, acrosome-reacted spermatozoa relative to the total population was determined at $3 \mathrm{~h}$ after incubation for each treatment (Fig. 5). The proportion of acrosome-reacted cells detected by FITC-CD46 fluorescence was 

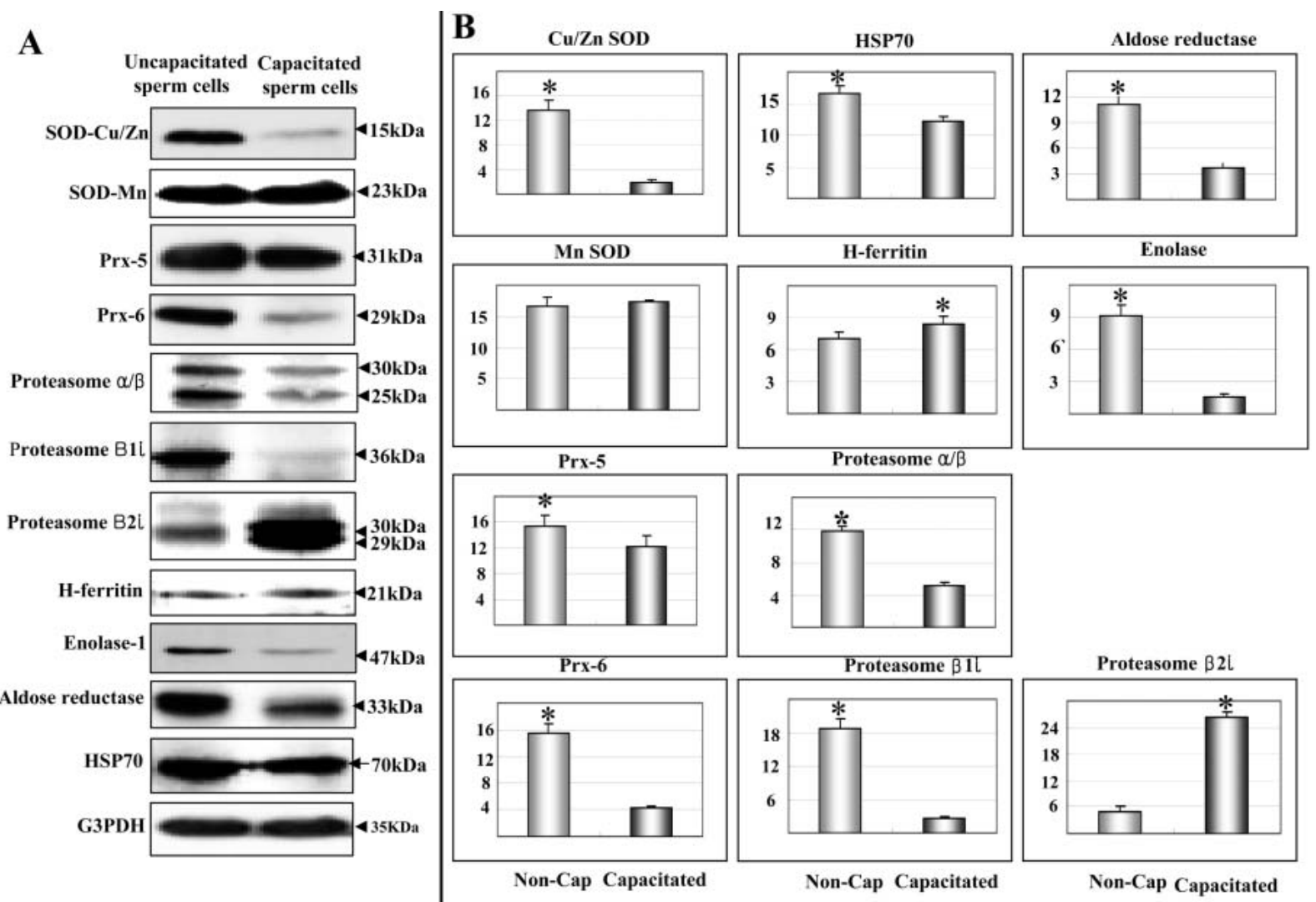

C
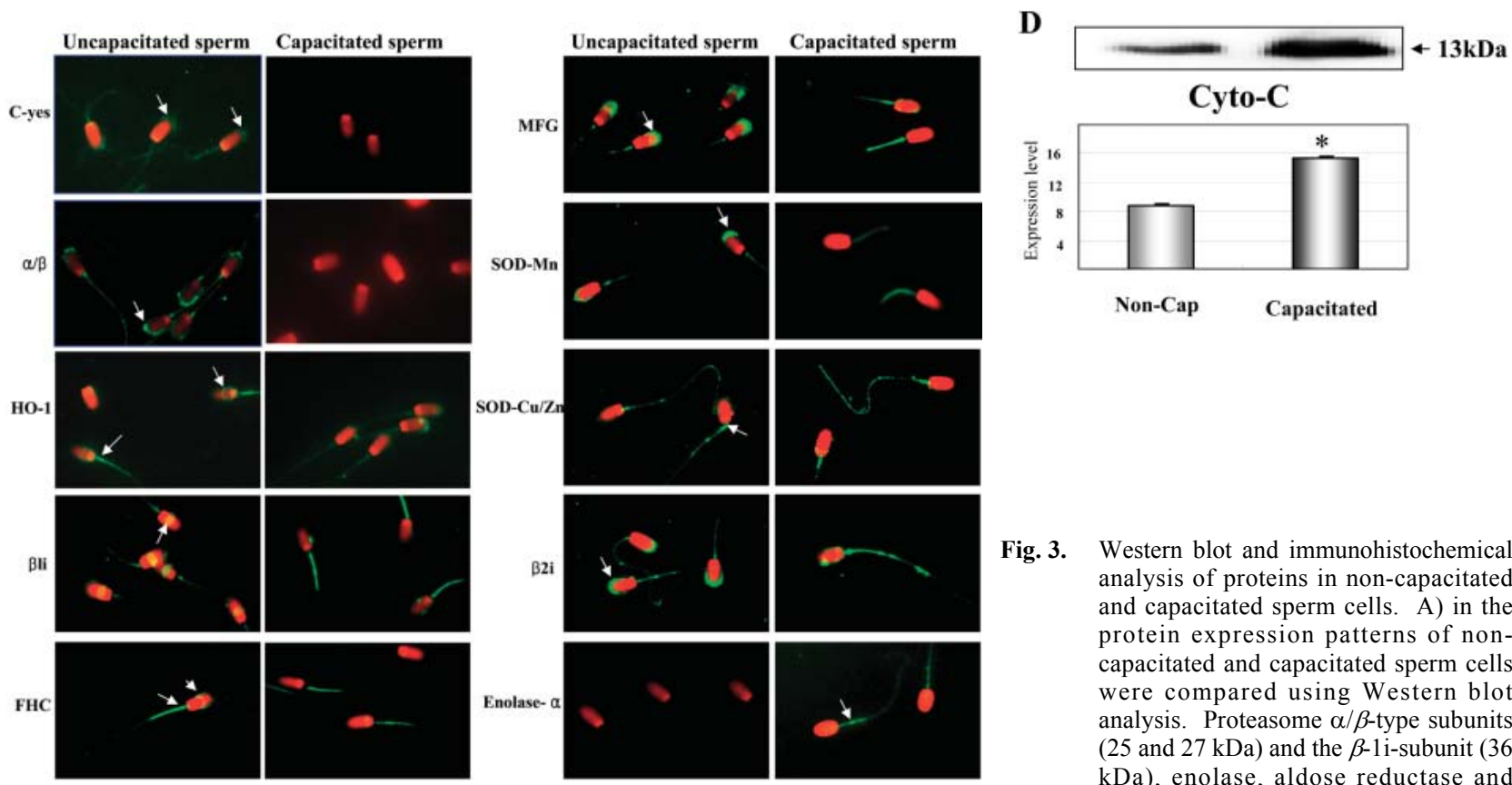

following incubation in $\mathrm{CM}$. However, the 29 and $30 \mathrm{kDa}$ subunits of proteasome $\beta-2 \mathrm{i}$ and $\mathrm{H}=\mathrm{feri}$ comparison data were extracted by westernblot intensity using personal densitometry. All experimental data are presented as means \pm SD $(\mathrm{P}<0.05)$ and $\mathrm{Y}$ axis is fold intensity. C) Localization of subjected proteins for western blot analysis in sperm incubated under non-capacitating or capacitating conditions. Arrows indicate each protein expression. In this figure, $\alpha / \beta, \mathrm{HO}-1, \beta \mathrm{li}$, FHC, and $\beta 2 \mathrm{i}$ indicate proteasome $\alpha / \beta$, Heme 4 oxygenase-1, proteasome $\beta$ li, ferritin heavy chain and proteasome $\beta 2 \mathrm{i}$, respectively. D) Westernblot analysis of cytochrome $\mathrm{c}$ expression. Each experiment was performed at least three times, and the data was subjected to statistical analysis $(\mathrm{P}<0.05)$ and $\mathrm{Y}$ axis is fold intensity. 
CM

0 h $\quad 0.5$ h $\quad 1$ h $\quad 3$ h $\quad 6 h \quad 9 h$
NCM
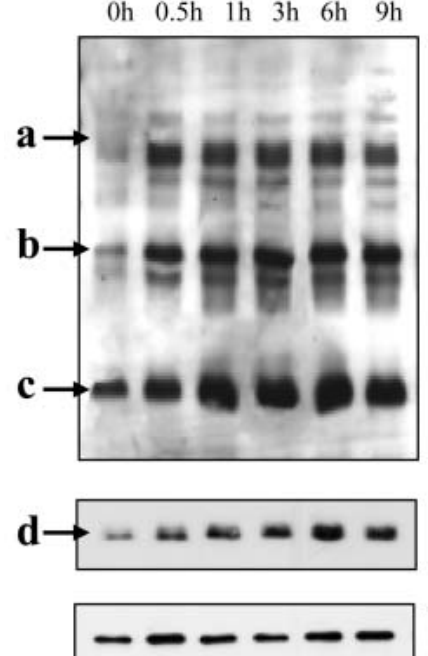

0h $0.5 \mathrm{~h} \quad 1 \mathrm{~h} \quad 3 \mathrm{~h} \quad 6 \mathrm{~h} \quad 9 \mathrm{~h}$
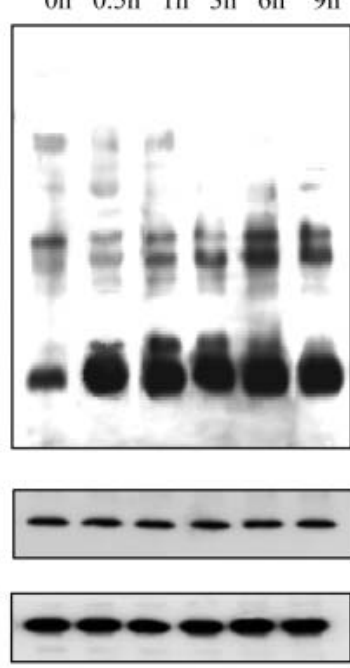

$\mathrm{NCM}+\mathrm{Cr}(\mathrm{Vl})$

0 h $0.5 \mathrm{~h} \quad 1 \mathrm{~h} \quad 3 \mathrm{~h} \quad 6 \mathrm{~h} \quad 9 \mathrm{~h}$
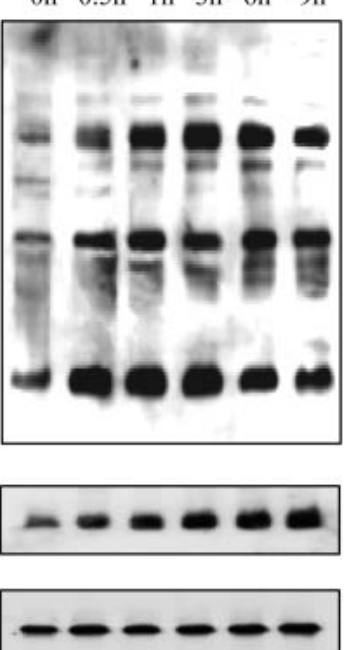

$\mathrm{NCM}+\mathrm{Cr}(\mathrm{Vl})+\mathrm{Cs} \mathrm{A}$

Oh $0.5 \mathrm{~h} \quad$ lh $3 \mathrm{~h} \quad 6 \mathrm{~h} \quad 9 \mathrm{~h}$
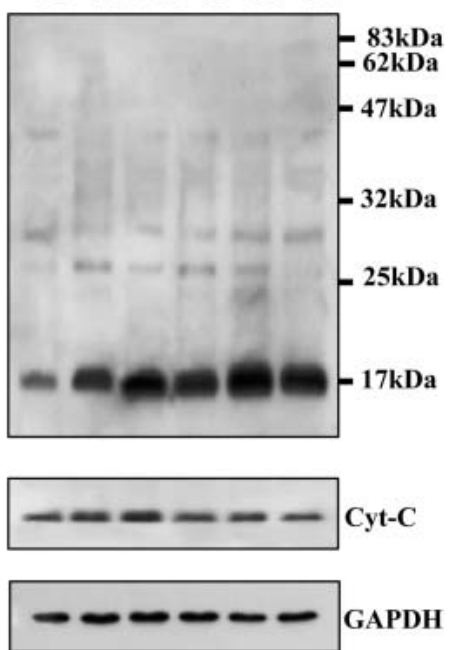

Fig. 4. Time course ( 0 to $9 \mathrm{~h})$ expression of capacitation-dependent cytochrome c and tyrosine-phosphorylated protein levels. Alteration of protein tyrosine phosphorylation and cytochrome c expression in sperm cells following incubation in CM, NCM, NCM supplemented with Cr(VI) and NCM supplemented with both $\mathrm{Cr}(\mathrm{VI})$ and CsA. Three major sets of tyrosine-phosphorylated proteins were detected; a, b and c are 47, 28 and 18 $\mathrm{kDa}$ phosphorylated proteins, respectively and $\mathrm{d}$ is the cytochrome $\mathrm{c}$ expression level under different conditions. Sperm cells incubated in NCM supplemented with $\mathrm{Cr}(\mathrm{VI})$, such as those of sperm cells cultured in $\mathrm{CM}$, demonstrated dose- and time-dependent upregulation of cytochrome c, which led to upregulation of protein tyrosine phosphorylation. Supplementation with CsA inhibited tyrosine phosphorylation of sperm proteins and cytochrome c expression. Note that, in pig sperm cells cultured in both NCM and CM, tyrosine phosphorylation of an approximately $18 \mathrm{kDa}$ protein increased (c). Sperm cells incubated in CM or NCM and supplemented with $\mathrm{Cr}(\mathrm{VI})$ demonstrated a higher level of cytochrome c expression throughout the incubation time course, whereas control and/or sperm cells incubated in NCM supplemented with both Cr(VI) and CsA demonstrated a constant level of expression.

A
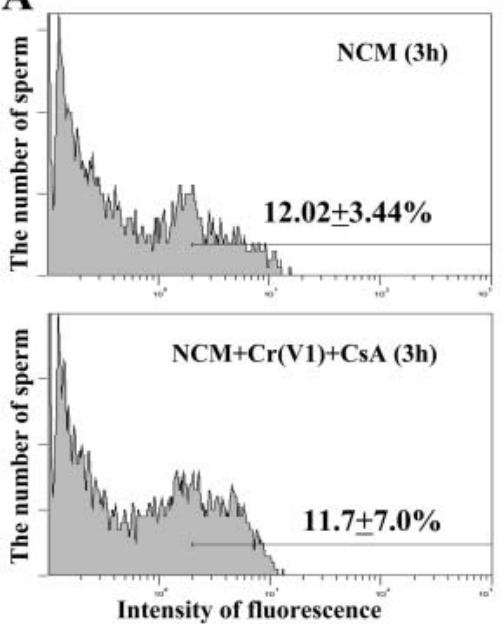
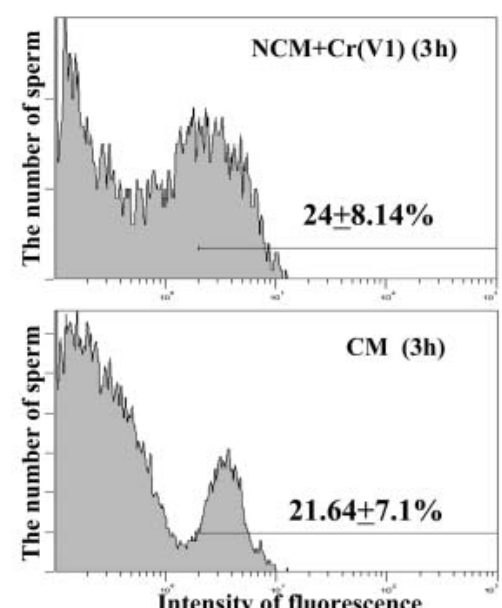

Intensity of fluorescence

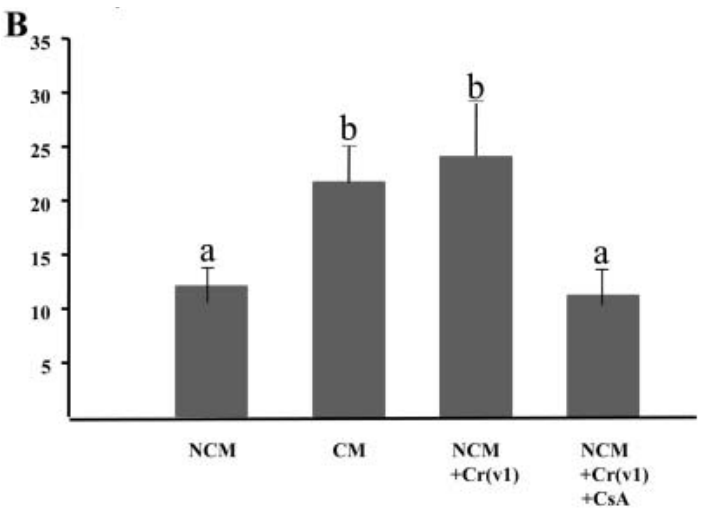

Fig. 5. Flow cytometry analysis with anti-CD46 antibody as a capacitation indicator. (A) The capacitation levels of pig sperm cells incubated for $3 \mathrm{~h}$ in $\mathrm{CM}$, NCM, NCM supplemented with $\mathrm{Cr}(\mathrm{VI})$, and NCM supplemented with $\mathrm{Cr}(\mathrm{VI})$ and CsA were analyzed by flow cytometry, respectively. (B) The data were normalized through statistical analysis. All experimental data are presented as means $\pm \mathrm{SD}(\mathrm{P}<0.05)$. Each experiment was performed at least three times and $\mathrm{Y}$ axis is expression of CD-46. significantly higher for $\mathrm{CM}(21.64+7.1 \%)$ and $\mathrm{NCM}+\mathrm{Cr}(\mathrm{VI})$ treatments $(24+8.14 \%)$ than for the NCM $(12.02+3.44 \%)$ and $\mathrm{NCM}+\mathrm{Cr}(\mathrm{VI})+\mathrm{CsA}(11.7+7.0 \%)$ treatments. In accord with the above observations, capacitation of sperm cells incubated in NCM supplemented with $\mathrm{Cr}(\mathrm{VI})$ increased in a manner corresponding with the increase of capacitation in $\mathrm{CM}$, indicating that cytochrome 

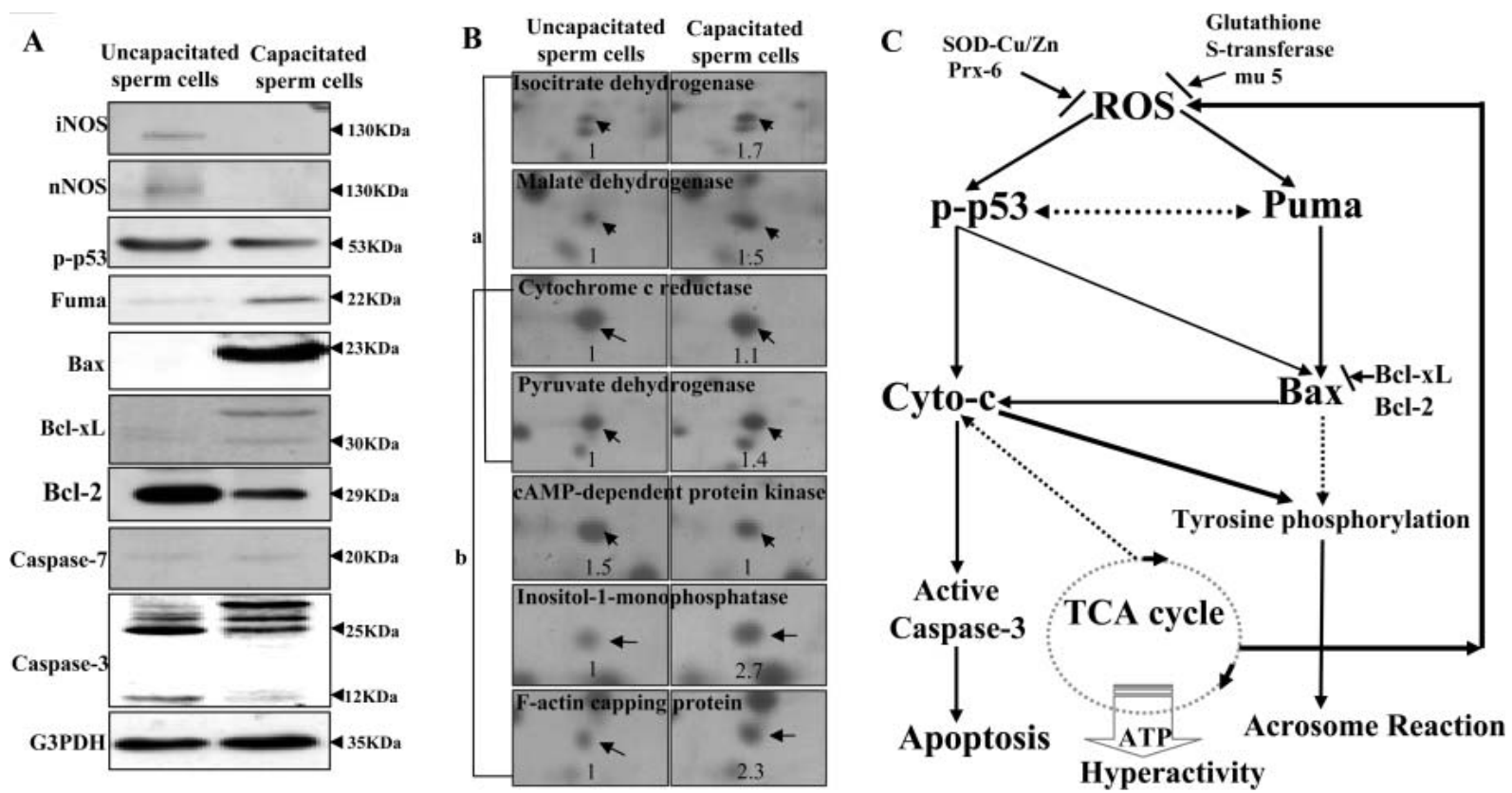

Fig. 6. A proposed mechanism of capacitation of pig sperm cells. (A) Non-capacitated sperm cells demonstrated high levels of activated p53, Bcl-2 and caspase-3 expression; however, Fuma and Bax expression were downregulated. Note that capacitated sperm cells demonstrated lowered expression of caspase-3, in spite of a higher expression of Fuma and Bax. (B) Close-up images of the region on the gels that showed the differentially expressed proteins in the non-capacitated and capacitated sperm cells, and each number on the 2-D gel indicates the relative expression. A and B refer to TCA cycle- and phosphorylation-related proteins, respectively. (C) Schematic depicting the sperm cells fate following capacitation. Three major signaling pathways are operating in the sperm cells, namely a Bax/cytochrome c-dependent caspase-3 pathway (cell death), a Bax/cytochrome c-tyrosine phosphorylation pathway (capacitation) and TCA cycle-dependent ATP production (hyperactivity).

c upregulation may be involved in signal transduction for sperm capacitation, rather than in the induction of apoptosis.

To elucidate the mechanism of capacitation induced by cytochrome c upregulation, we quantified the apoptosis - related protein expression via cytochrome c by western immunoblot analysis. After incubation for $3 \mathrm{~h}$ under capacitating conditions, expression of Puma and Bax was significantly elevated, whereas expression of the apoptotic "executor" protease, caspase-3, was undetectable (Fig. 6A). In addition, the caspase-7 and phosphorylated p53 protein levels were similar. This data implies that the upregulation of cytochrome $\mathrm{c}$ is strongly related to Puma and Bax expression. Furthermore, upregulated cytochrome $\mathrm{c}$ does not activate caspase- 3 to apoptosis, but may activate capacitation through the TCA cycle. Based on the fact that sperm cells cultured in CM demonstrated temporally-dependent increases in protein tyrosine phosphorylation and cytochrome c expression, we, therefore, suggest that sperm cells undergo the capacitation and post-capacitational process rather than apoptosis when cultured in CM (Fig. 6C and sFig. 2).

\section{Discussion}

Proteomics can be used as a tool for the detection of capacited and spontaneously acrosome-related biomarker proteins

In this study, the well-established biomarkers of capacitation, such as lactadherin (P47) [30], As-A [31], acrosomal protein SP-10 precursor (SP-10) [32], prohibitin [33], proteasomes [34, 35] and DJ-1 protein [36], were identified. SP-10 is a testis-specific acrosomal protein that has been detected in several species, including humans. Previous studies have demonstrated that colloidal gold labeling of SP-10 is greatest within the principal segment and posterior bulb of the equatorial segment of the acrosome, but sparse in the anterior equatorial segment [32]. In our study, three isoforms of SP-10 were detected; $\mathrm{pI}$ and $\mathrm{Mr}$ were approximately $\mathrm{pI}=4.68$ (spots 23 and 24; 28 and $26 \mathrm{kDa}$ proteins, respectively) and $\mathrm{pI}=6$ (spot 25, a $22 \mathrm{kDa}$ protein). Among them, the $22 \mathrm{kDa}$ isoform of $\mathrm{Sp}-10$ was strongly methylated during capacitation and spontaneous acrosome reaction, and all three isoforms showed significant increases in expression levels compared with fresh sperm (control). In humans, eleven RT-PCR products of SP-10 have been identified and characterized [37]. Among them, the longest SP-10 mRNA is the most abundant form, comprising $53-72 \%$ of the total message. On the other hand, the second, third and fourth largest forms had expression levels of $15-32,3.4-8.3$ and $8.7-12.5 \%$, respectively. Our data suggests that heterogeneous forms of SP-10 are caused by alternative splicing and that these isoforms may play an important role in sperm capacitation and spontaneous acrosome reaction.

DJ-1 is a multifunctional protein that plays essential roles in tissues with higher order biological functions, such as the testes and brain. A previous study reported that anti-DJ-1 antibody inhibits fusion of sperm with an oocyte and DJ-1 is present on the surface of the posterior part of the head and anterior part of the midpiece of 
ejaculated spermatozoa [38]. This suggested that DJ-1 has two potential roles in fertilization: binding to the egg and flagella movement. However, in this study, the abundance of DJ-1 in capacitated sperm cells decreased (Fig. 2B, spot 58). Therefore, its importance and role in binding to eggs is still in question. Previous studies have demonstrated that $\mathrm{P} 47$ appears to migrate from the apical ridge onto the entire acrosomal region [30], and As-A staining was observed in the heads of live caudal epididymal and vas deferens sperm [31]. In this study, we found that As-A (spot 3) expression increased during capacitation and spontaneous acrosome reaction, whereas P47 (spot 45) expression decreased. However, studies have shown that As-A-disrupted mice produce progeny successfully [39], indicating that it is not critical for induction of capacitation in mature sperm cells. Collectively, identification of these proteins supported the use of proteomics as a tool for identification of novel biomarkers following induction of capacitation and spontaneous acrosome reaction.

\section{CCT- $\gamma$ and $-\varepsilon$ are essential factors for capacitation of pig sperm cells}

Chaperonin subunit CCT- $\alpha$ was first identified in the testis by 2D gel electrophoreses [40], and its expression increases at the onset of meiosis and sperm differentiation [41]. In eukaryotes, CCT is constructed from eight subunits that are expressed ubiquitously; CCT (also referred to as TCP-1)- $\alpha,-\beta,-\gamma,-\delta,-\varepsilon,-\zeta,-\eta$ and $-\theta$ share about $30 \%$ sequence identity and are conserved from yeasts to mammals [42-45]. In this study, CCT- $\gamma$ and $-\varepsilon$ increased during capacitation and spontaneous acrosome reaction, whereas CCT- $\alpha$, $-\beta,-\delta,-\zeta,-\eta$ and $-\theta$ were either not detected or maintained constant expression levels. Methionine-demethylated CCT- $\varepsilon$ protein expression (spot 8) increased significantly following induction of capacitation and spontaneous acrosome reaction, whereas methylated CCT- $\varepsilon$ expression (spot 9) decreased significantly. In the mature spermatozoon, CCT was scattered through the condensed chromatin structures, yet in typical interphasic cells, it was concentrated at the constitutive heterochromatin. CCT appears to be required at condensed or condensing regions of DNA. A functional association between CCT and microtubules is supported by identification of soluble binary complexes between $\gamma$-tubulin and CCT [45]. Overall, recruitment of CCT to the microtubule organizing centres is a key determinant of proper cytoskeletal assembly and/or maintenance in somatic cells; by analogy, the same is probably true for sperm cells [46]. Therefore, we suggest that CCT- $\varepsilon$ demethylation may be required for recruitment of CCT to microtubule organizing centres in capacitated and spontaneously acrosomereacted sperm cells and that CCT- $\gamma$ and $-\varepsilon$, but not CCT $-\beta,-\delta,-\zeta,-\eta$ or $-\theta$, may play specific and/or essential roles in remodeling of the sperm nucleus during and after capacitation.

\section{Twenty-nine and $30 \mathrm{kDa}$ proteasomes are involved in capacitation of pig sperm cells}

In our 2-D gel analysis, we demonstrated that incubation of mature pig sperm cells for $3 \mathrm{~h}$ in CM induces a change in proteasome subunit composition, with the $\alpha$ type 3 (spot 26) and $\beta$ type 6 (spot 21) levels increasing significantly, whereas expression of alpha type 6 decreased (Fig. 2B: increase in spot 56 ). Serum des- ignated $\alpha / \beta$ was raised against a proteasomal preparation isolated from human red blood cells [47], thus recognizing a set of bands between 20 and $30 \mathrm{kDa}$ in human erythrocyte lysate and higher molecular weight (MW) bands in other cell lysates. In humans, multiple $\alpha$ - and $\beta$-type subunits, namely $\alpha-5, \alpha-6, \alpha-7, \beta-1, \beta-5, \beta$ $5 \mathrm{i}$ and $\beta$-7, are recognized by this serum [47]. Even though serum $\alpha / \beta$ recognized a set of bands between 25 and $30 \mathrm{kDa}$, their expression in Western blot analysis despite higher 2-D gel levels, were significantly reduced. There are multiple technical considerations with regard to both Western blot and 2-D gel expression levels that affect the results. Since this serum recognized a set of bands between 25 and $30 \mathrm{kDa}$ (Fig. 3A), it is possible that human-derived $\alpha / \beta$ serum does not recognize pig-derived $\alpha$ type 3 and $\beta$ type 6 . In addition, proteasome anti- $\beta 2 \mathrm{i}$ serum recognized 29 and $30 \mathrm{kDa}$ protein expression, which increased significantly following induction of capacitation and spontaneous acrosome reaction. The function of the proteasome is well characterized in relation to salmon spermatozoa [48]. In those cells, the proteasomes are involved in ATP-dependent regulation of sperm motility by modulating the activity of the outer arm dynein through regulation of cAMP. An association between proteasomes and sperm motility has been described in mammals, but application of proteasome inhibitors does not affect the motility of spermatozoa [35]. In other animals, such as the ascidian, proteasomes are involved in sperm binding to the zona pellucida and sperm penetration [34]. Our data suggests that the increased expression of alpha type 3, beta type 6 and anti- $\beta 2 \mathrm{i}$ recognized proteins, 29 and $30 \mathrm{kDa}$, may play a direct role in maintaining the cellular homeostasis of spermatozoa during the capacitation and spontaneous acrosome reaction process and/or in penetration of the zona pellucida.

\section{Differential expression of antioxidant enzymes during capacitation and spontaneous acrosome reaction}

Energy deprivation due to utilization of ATP by sperm cells may lead to accumulation of lactic acid, resulting in exposure to oxidative stress molecules, such as ROSs. Although the cellular superoxide anion $\left(\mathrm{O}_{2}^{-}\right)$is a normal byproduct of the mitochondrial electron transport chain [49], dismutation of $\mathrm{O}_{2}{ }^{--}$yields the relatively stable hydrogen peroxide $\left(\mathrm{H}_{2} \mathrm{O}_{2}\right) . \quad \mathrm{H}_{2} \mathrm{O}_{2}$ can produce the highly reactive hydroxyl radical $(\mathrm{OH})$ through the Fenton reaction. SOD catalyzes the dismutation of $\mathrm{O}_{2}-$ to $\mathrm{H}_{2} \mathrm{O}_{2}$, and ferritin sequesters intracellular iron, which reduces the iron-dependent Fenton reaction. During induction of capacitation and spontaneous acrosome reaction, the enzyme levels of $\mathrm{Cu}-\mathrm{Zn} \mathrm{SOD}$, peroxiredoxin- 5 and peroxiredoxin -6 declined significantly, but the level of $\mathrm{H}$-ferritin sharply increased (Fig. 3A). Furthermore, glutathione S-transferase mu 5 (spot 35), which detoxifies reactive aldehydes, was upregulated during capacitation and spontaneous acrosome reaction. Reactive aldehydes are formed primarily through lipid peroxidation and are particularly deleterious to mitochondrial function. Taken together, it is possible that the $\mathrm{Cu}-\mathrm{Zn}$ SOD, peroxiredoxin- 5 and peroxiredoxin- 6 enzymes play critical roles in removal of superoxide anions that are generated at the beginning of capacitation and spontaneous acrosome reaction. On the other hand, glutathione S-transferase mu 5 and $\mathrm{H}$-ferritin might act to scavenge reactive hydroxyl radicals that are caused by late stages 
of capacitation and spontaneous acrosome reaction.

\section{Cytochrome c upregulation directly triggers tyrosine phosphorylation of sperm cell proteins}

Protein tyrosine phosphorylation is considered to be a hallmark of sperm cell capacitation $[11,50]$. However, the molecular mechanisms involved in tyrosine phosphorylation for sperm capacitation are not clearly understood. In the present study, different medium components were examined to establish their importance in relation to pig sperm capacitation and associated signaling events. Using an anti-tyrosine phosphorylation antibody, we found 3 major sets of tyrosine phosphorylated proteins $(48,28$ and $18 \mathrm{kDa})$ in acrosome-reacted pig sperm cells. The appearance of the p48 and p28 proteins coincide with the increased numbres of acrosome reacted sperm cells, suggesting that these proteins are tyrosine kinase substrates, that undergo phosphorylation during capacitation. A previous study [51] demonstrated that a $48 \mathrm{kDa}$ protein was the FA-1 antigen, which is known to play an important role in capacitation and sperm-ZP binding. Additionally, we detected one major $(18 \mathrm{kDa})$ and three minor $(28,26$ and $19 \mathrm{kDa})$ tyrosine phosphorylated proteins in sperm cells incubated in NCM. Among these, the $\mathrm{p} 18$ protein increased significantly when incubated under all culture conditions [NCM, CM, NCM containing $\mathrm{Cr}(\mathrm{VI})$ and $\mathrm{NCM}$ containing $\mathrm{Cr}(\mathrm{VI})+\mathrm{CsA}$ ] (Fig 4). In addition, these proteins $(48,28,26,19$ and $18 \mathrm{kDa})$ increased in sperm tail-derived proteins, but not for sperm head-derived protein (data not shown). This result is particularly interesting, since previous studies have reported that the flagella of pig sperm, unlike those of other species, does not undergo tyrosine phosphorylation [19]. In this study, however, we did not find the approximately 94 and $32 \mathrm{kDa}$ proteins as reported by Leyton and Saling [52]. These proteins have been observed in mouse spermatozoa. However, the medium described by Tardif [53] contains $25 \mathrm{mM}$ of bicarbonate, which is relatively high and produces faster changes. This capacitation medium appears to be slightly hypoosmotic according to its composition. Therefore, this discrepancy may be due to the individual culture conditions used or species differences.

\section{Perturbation of energy metabolism in capacitated sperm cells}

Capacitation is also linked to events that occur in the sperm flagellum [54]. Enolase (spot 44) is involved in anaerobic glycolysis, and its levels decreased significantly following induction of capacitation. Its expression was found in the tails of mature spermatozoa, but disappeared after induction of capacitation and spontaneous acrosome reaction (Fig. 3C). This enzyme is critical for the glycolytic pathway and promotes promoting the reversible removal of a water molecule from 2-phosphoglycerate to yield phosphoenolpyruvate, a high-energy phosphate compound. In this study, 2-D gel analysis revealed that sperm cells incubated under capacitating conditions showed increased expression levels of MDH (spot 50), IDH (spot 43), Vacuolar ATP synthase catalytic subunit $\alpha$ (spot 2) and pyruvate dehydrogenase (spot 38) compared with control, non-capacitated sperm cells. The citric acid cycle is an oxidative metabolic pathway regulated by citrate synthase, IDH and $\alpha$-ketoglutarate dehydrogenase (Fig. 6B). IDH is considered to be the main regulatory enzyme, and its enzymatic activity is present in different forms, two mitochondrial $[\mathrm{NAD}(\mathrm{P})]$ and one cytosolic (NADP) [55]. As shown in Figs. 2B and 6B, the levels of IDH (spot 43) increased significantly during capacitation and spontaneous acrosome reaction, indicating that participation of the malate-aspartate shuttle may be required to maintain the levels of reduced coenzyme necessary for capacitation and spontaneous acrosome reaction. Furthermore, the level of the $\beta$-subunit of ATP synthesis (which is the catalytic subunit producing ATP from ADP in the presence of a proton gradient across the mitochondrial membrane [55] ) was upregulated in sperm cells incubated under capacitating conditions (Fig. 2, spot 5). Even though we did not detect peptides for glucokinase or pyruvate kinase due to their low levels in the sperm cells, systematic identification of these two glycolytic enzymes may reveal additional links between glucose metabolism and sperm mobility. Collectively, our observations suggest that energy metabolism for sperm hyperactivity may occur via the glycolytic pathway.

In sperm cells incubated under capacitating conditions, there is upregulation of Bax or Fuma expression via p53 phosphorylation and downregulation of active caspase- 3 expression (Fig. 6 and sFig. 2A). In this study, we demonstrated that exposure of pig sperm cells to $\mathrm{Cr}(\mathrm{VI})$, in NCM or CM, causes dose- and timedependent upregulation of cytochrome $\mathrm{c}$, leading to upregulation of protein tyrosine phosphorylation and capacitation and spontaneous acrosome reaction (Figs. 4 and 5). However, previous studies indicate that initiation of apoptotic events is not involved in the processes of membrane modification and destabilization in porcine and human sperm under conditions of in vitro incubation [56, 57] and that bicarbonate-induced scrambling during capacitation is not an apoptotic process [58]. In addition, we also have not shown clearly that apoptotic events happen during capacitation and spontaneous acrosome reaction. However, we did show that the cytochrome c levels increased in sperm tails, but not sperm heads, during incubation with sodium chromate for $6 \mathrm{~h}$ (sFig. 2B). Collectively, our observations strongly suggest that upregulation of cytochrome c may be involved in signal transduction for sperm capacitation and spontaneous acrosome reaction, rather than in induction of apoptosis (Figs. 6A and C).

In this study, we found several proteins that had post-translational modifications, including phophorylation [cAMP-dependent protein kinase type-1 alpha regulatory subunit (spot 10), inositol-1monophosphatase (spot 18), pyruvate dehydrogenase (spot 38), Factin capping protein (spots 39 and 40), ubiquinol cytochrome c reductase (spot 11) and glutathione S-transferase M5 (spot 35)], methylation [F-actin capping protein $\beta$ (spot 40$)$, SP-10 (spot 25) and CCT- $\varepsilon$ (spot 8)] and limited proteolysis [Tetratricopeptide repeat protein 14 (spot 15)]. In conclusion, it is important to note that most of the earlier studies on capacitation in spermatozoa have used tyrosine phosphorylation antibodies in various ways, and thus the contribution of these extra proteins might have been overlooked. To our knowledge, this is the first study considering whole proteome alternations in capacitated sperm cells, and it has demonstrated that the amount of cytochrome c upregulation determines the fate of sperm, such as capacitation and spontaneous acrosome reaction or cell death (Fig. 6). 


\section{Acknowledgements}

The authors are greatly indebted to Drs E. Töpfer-Petersen and A. Petrunkina (University of Hannover, Germany) and Dr. R. Yanagimachi (University of Hawaii, USA) for helpful discussion and support concerninf this work. We are most grateful to Dr. H-G Seo (GyeongSang National University, Korea) for kindly providing antibodies against SOD-Mn, SOD-Zn/Cu, iNO and eNO. This study was supported in part by the Agriculture Special Tax Program administered by the ARPC of Korea.

\section{References}

1. Leclerc $\mathbf{P}$, Goupil S. Regulation of the human sperm tyrosine kinase c-yes. Activation by cyclic adenosine 3',5'-monophosphate and inhibition by $\mathrm{Ca}^{2+}$. Biol Reprod 2002; 67: 301-307.

2. Weil M, Jacobson MD, Raff MC. Are caspases involved in the death of cells with a transcriptionally inactive nucleus? Sperm and chicken erythrocytes. J Cell Sci 1998; 111: 2707-2715.

3. Gur Y, Breitbart H. Mammalian sperm translate nuclear-encoded proteins by mitochondrial-type ribosomes. Gene Dev 2006; 20: 411-416.

4. Sotolongo B, Ward WS. DNA loop domain organization: the three-dimensional genomic code. J Cell Biochem Suppl 2000; 35: 23-26.

5. Schmidt H, Kamp G. Induced hyperactivity in boar spermatozoa and its evaluation by computer-assisted sperm analysis. Reproduction 2004; 128: 171-179.

6. Abou-Haila A, Tulsiani DR. Mammalian sperm acrosome: formation, contents, and function. Arch Biochem Biophys 2000; 379: 173-182

7. Felix R. Molecular physiology and pathology of $\mathrm{Ca}^{2+}$-conducting channels in the plasma membrane of mammalian sperm. Reproduction 2005; 129: 251-262.

8. Harrison RA, Gadella BM. Bicarbonate-induced membrane processing in sperm capacitation. Theriogenology 2005; 15: 342-351.

9. Breitbart H, Cohen G, Rubinstein S. Role of actin cytoskeleton in mammalian sperm capacitation and the acrosome reaction. Reproduction 2005; 129: 263-268.

10. Kumar P, Meizel S. Nicotinic acetylcholine receptor subunits and associated proteins in human sperm. J Biol Chem 2005; 280, 25928-25935.

11. Mitra K, Rangaraj N, Shivaji S. Novelty of the pyruvate metabolic enzyme dihydrolipoamide dehydrogenase in spermatozoa: correlation of its localization, tyrosine phosphorylation, and activity during sperm capacitation. J Biol Chem 2005; 280: 2574325753.

12. Bagchi D, Bagchi M, Stohs SJ. Chromium (VI)-induced oxidative stress, apoptotic cell death and modulation of p53 tumor suppressor gene. Mol Cell Biochem 2001; 222: 149158.

13. Pritchard DE, Singh J, Carlisle DL, Patierno SR. Cyclosporin A inhibits chromium(VI)-induced apoptosis and mitochondrial cytochrome $\mathrm{c}$ release and restores clonogenic survival in CHO cells. Carcinogenesis 2000; 21: 2027-2033.

14. Bosgelmez II, Guvendik G. Effects of taurine on oxidative stress parameters and chromium levels altered by acute hexavalent chromium exposure in mice kidney tissue. Biol Trace Elem Res 2004; 102: 209-225.

15. Choi YJ, Song H, Kwon DN, Cho SK, Kang SJ, Yoe SM, Kim HC, Lee HT, Park C, Kim JH. Significant IgG-immunoreactivity of the spermatogonia of the germ celldepleted testis after busulfan treatment. Anim Reprod Sci 2006; 91: 317-335.

16. Johnson LA, Aalbers JG, Grooten HJG. 1988. Artificial insemination of swine: fecundity of boar semen stored in Beltsville TS (BTS), Modified Modena (MM), or MR-A and inseminated on one, three and four days after collection. Zuchthygiene 1988; 23: 49-55.

17. Petrounkina AM, Harrison RA, Petzoldt R, Weitze KF, Topfer-Petersen E. Cyclical changes in sperm volume during in vitro incubation under capacitating conditions: a novel boar semen characteristic. I Reprod Fertil 2000; 118: 283-293.

18. Toyoda $\mathbf{Y}$, Chang MC. Capacitation of epididymal spermatozoa in a medium with high K-Na ratio and cyclic AMP for the fertilization of rat eggs in vitro. J Reprod Fertil 1974; 36: 125-134.

19. Tardif S, Lefievre L, Gagnon C, Bailey JL. Implication of cAMP during porcine sperm capacitation and protein tyrosine phosphorylation. Mol Reprod Dev 2004; 69: 428-435.

20. Yudin AI, Vandevoort CA, Li MW, Overstreet JW. PH-20 but not acrosin is involved in sperm penetration of the macaque zona pellucida. Mol Reprod Dev 1999; 53: 350-362.

21. Pereira RJ, Tuli RK, Wallenhorst S, Holtz W. The effect of heparin, caffeine and calcium ionophore A23187 on in vitro induction of the acrosome reaction in frozen- thawed bovine and caprine spermatozoa. Theriogenology 2000; 54:185-192.

22. Park MR, Cho SK, Lee SY, Choi YJ, Park JY, Kwon DN, Son WJ, Paik SS, Kim T, Han YM, Kim JH. A rare and often unrecognized cerebromeningitis and hemodynamic disorder: a major cause of sudden death in somatic cell cloned piglets. Proteomics 2005; 5: 1928-1939.

23. Lee KH, Bae DW, Lim DB. Evaluation of parameters in peptide mass fingerprinting for protein identification by MALDI-TOF mass spectrometry. Mol Cells 2002; 13: 175184 .

24. Sanchez JC, Ravier F, Pasquali C, Frutiger S, Paquet N, Bjellqvist B, Hochstrasse DF, Hughes GL. Improving the detection of proteins after transfer to polyvinylidene difluoride membranes. Electrophoresis 1992; 13: 715-717.

25. Choi YJ, Ok DW, Kwon DN, Chung JI, Kim HC, Yeo SM, Kim T, Seo HG, Kim JH Murine male germ cell apoptosis induced by busulfan treatment correlates with loss of c-kit-expression in a Fas/FasL- and p53-independent manner. FEBS Lett 2004; 575 41-51.

26. Tehranchi R, Invernizzi R, Grandien A, Zhivotovsky B, Fadeel B, Forsblom AM, Travaglino E, Samuelsson J, Hast R, Nilsson L, Cazzola M, Wibom R, HellstromLindberg E. Aberrant mitochondrial iron distribution and maturation arrest characterize early erythroid precursors in low-risk myelodysplastic syndromes. Blood 2005, 106: 247-253.

27. Andrabi SA, Spina MG, Lorenz P, Ebmeyer U, Wolf G, Horn TF. Oxyresveratrol (trans-2,3',4,5'-tetrahydroxystilbene) is neuroprotective and inhibits the apoptotic cell death in transient cerebral ischemia. Brain Res 2004; 1017: 98-107.

28. Zhang P, Liu B, Kang SW, Seo MS, Rhee SG, Obeid LM. Thioredoxin peroxidase is a novel inhibitor of apoptosis with a mechanism distinct from that of Bcl-2.J Biol Chem 1997; 272: 30615-30618.

29. Kanno T, Sato EE, Muranaka S, Fujita H, Fujiwara T, Utsumi T, Inoue M, Utsumi K Oxidative stress underlies the mechanism for $\mathrm{Ca}(2+)$-induced permeability transition of mitochondria. Free Radic Res 2004; 38: 27-35.

30. Petrunkina AM, Lakamp A, Gentzel M, Ekhlasi-Hundrieser M, Topfer-Petersen E Fate of lactadherin P47 during post-testicular maturation and capacitation of boar spermatozoa. Reproduction 2003; 125: 377-387.

31. Weerachatyanukul W, Xu H, Anupriwan A, Carmona E, Wade M, Hermo L, da Silva SM, Rippstein P, Sobhon P, Sretarugsa P, Tanphaichitr N. Acquisition of arylsulfatase A onto the mouse sperm surface during epididymal transit. Biol Reprod 2003; 69 : 1183-1192.

32. Foster JA, Klotz KL, Flickinger CJ, Thomas TS, Wright RM, Castillo JR, Herr JC Human SP-10: acrosomal distribution, processing, and fate after the acrosome reaction. Biol Reprod 1994; 51: 1222-1231.

33. Thompson WE, Ramalho-Santos J, Sutovsky P. Ubiquitination of prohibitin in mammalian sperm mitochondria: possible roles in the regulation of mitochondrial inherit ance and sperm quality control. Biol Reprod 2003; 69: 254-260.

34. Sutovsky P, Manandhar G, McCauley TC, Caamano JN, Sutovsky M, Thompson WE, Day BN. Proteasomal interference prevents zona pellucida penetration and fertilization in mammals. Biol Reprod 2004; 71: 1625-1637.

35. Tipler CP, Hutchon SP, Hendil K, Tanaka K, Fishel S, Mayer RJ. Purification and characterization of $26 \mathrm{~S}$ proteasomes from human and mouse spermatozoa. Mol Hum Reprod 1997; 3: 1053-1060.

36. Takahashi K, Taira T, Niki T, Seino C, Iguchi-Ariga SM, Ariga H. DJ-1 positively regulates the androgen receptor by impairing the binding of PIASx $\alpha$ to the receptor. Biol Chem 2001; 276: 37556-37563.

37. Freemerman AJ, Flickinger CJ, Herr JC. Characterization of alternatively spliced human SP-10 mRNAs. Mol Reprod Dev 1995; 41: 100-108.

38. Yoshida K, Sato Y, Yoshiike M, Nozawa S, Ariga H, Iwamoto T. Immunocytochemical localization of DJ-1 in human male reproductive tissue. Mol Reprod Dev 2003; 66 : 391-397.

39. Hess B, Saftig P, Hartmann D, Coenen R, Lullmann-Rauch R, Goebel HH, Evers M, von Figura K, D'Hooge R, Nagels G, De Deyn P, Peters C, Gieselmann V. Phenotype of arylsulfatase A-deficient mice: relationship to human metachromatic leukodystrophy. Proc Natl Acad Sci USA 1996; 93: 14821-14826.

40. Silver LM, Artzt K, Bennett D. A major testicular cell protein specified by a mouse T/ t complex gene. Cell 1979; 17: 275-284.

41. Silver LM, Kleene KC, Distel RJ, Hecht NB. Synthesis of mouse t complex protein during haploid stages of spermatogenesis. Dev Biol 1987; 119: 605-608.

42. Willison KR, Hynes G, Davies P, Goldsborough A, Lewis VA. Expression of three tcomplex genes, Tcp-1, D17Leh117c3, and D17Leh66, in purified murine spermatogenic cell populations. Genet Res 1990; 56: 193-201.

43. Kubota H, Hynes G, Carne A, Ashworth A, Willison K. Identification of six Tcp-1related genes encoding divergent subunits of the TCP-1-containing chaperonin. $\mathrm{Curr}$ Biol 1994; 4: 89-99.

44. Kubota H, Hynes G, Willison K. The eighth Cct gene, Cctq, encoding the theta subunit of the cytosolic chaperonin containing TCP-1. Gene 1995; 154: 231-236. 
45. Kubota H, Hynes GM, Kerr SM, Willison KR. Tissue-specific subunit of the mouse cytosolic chaperonin-containing TCP-1. FEBS Lett 1997; 402: 53-56.

46. Martin-Benito J, Boskovic J, Gomez-Puertas P, Carrascosa JL, Simons CT, Lewis SA, Bartolini F, Cowan NJ, Valpuesta JM. Structure of eukaryotic prefoldin and of its complexes with unfolded actin and the cytosolic chaperonin CCT. EMBO J 2002; 21: 6377-6386.

47. Mayr J, Wang HR, Nederlof P, Baumeister W. The import pathway of human and Thermoplasma 20S proteasomes into HeLa cell nuclei is different from that of classical NLS-bearing proteins. Biol Chem 1999; 380: 1183-1192.

48. Inaba K, Akazome Y, Morisawa M. Purification of proteasomes from salmonid fish sperm and their localization along sperm flagella. J Cell Sci 1993; 104: 907-915.

49. de Lamirande E, Gagnon C. Paradoxical effect of reagents for sulfhydryl and disulfide groups on human sperm capacitation and superoxide production. Free Radic Biol Med 1998; 25: 803-817.

50. Leclerc P, de Lamirande E, Gagnon C. Regulation of protein-tyrosine phosphorylation and human sperm capacitation by reactive oxygen derivatives. Free Radic Biol Med 1997; 22: 643-656.

51. Naz RK, Ahmad K. Molecular identities of human sperm proteins that bind human zona pellucida: nature of sperm-zona interaction, tyrosine kinase activity, and involvement of FA-1. Mol Reprod Dev 1994; 39, 397-408.
52. Leyton L, Saling P. $95 \mathrm{kd}$ sperm proteins bind ZP3 and serve as tyrosine kinase substrates in response to zona binding. Cell 1989; 30: 1123-1130.

53. Tardif S, Dube C, Chevalier S, Bailey JL. Capacitation is associated with tyrosine phosphorylation and tyrosine kinase-like activity of pig sperm proteins. Biol Reprod 2001; 65: 784-792

54. Yunes R, Doncel GF, Acosta AA. Incidence of sperm-tail tyrosine phosphorylation and hyperactivated motility in normozoospermic and asthenozoospermic human sperm samples. Biocell 2003; 27: 29-36.

55. Cordoba M, Pintos L, Beconi MT. Differential activities of malate and isocitrate $\mathrm{NAD}(\mathrm{P})$-dependent dehydrogenases are involved in the induction of capacitation and acrosome reaction in cryopreserved bovine spermatozoa. Andrologia 2005; 37: 40-46.

56. Gadella BM, Harrison RA. Capacitation induces cyclic adenosine 3',5'-monophosphate-dependent, but apoptosis-unrelated, exposure of aminophospholipids at the apical head plasma membrane of boar sperm cells. Biol Reprod 2002; 67: 340-350.

57. Martin G, Sabido O, Durand P, Levy R. Phosphatidylserine externalization in human sperm induced by calcium ionophore A23187: relationship with apoptosis, membrane scrambling and the acrosome reaction. Hum Reprod 2005; 20: 3459-3468.

58. Petrunkina AM, Jebe E, Töpfer-Petersen E. Regulatory and necrotic volume increase in boar spermatozoa. J Cell Physiol 2005; 204: 508-521. 

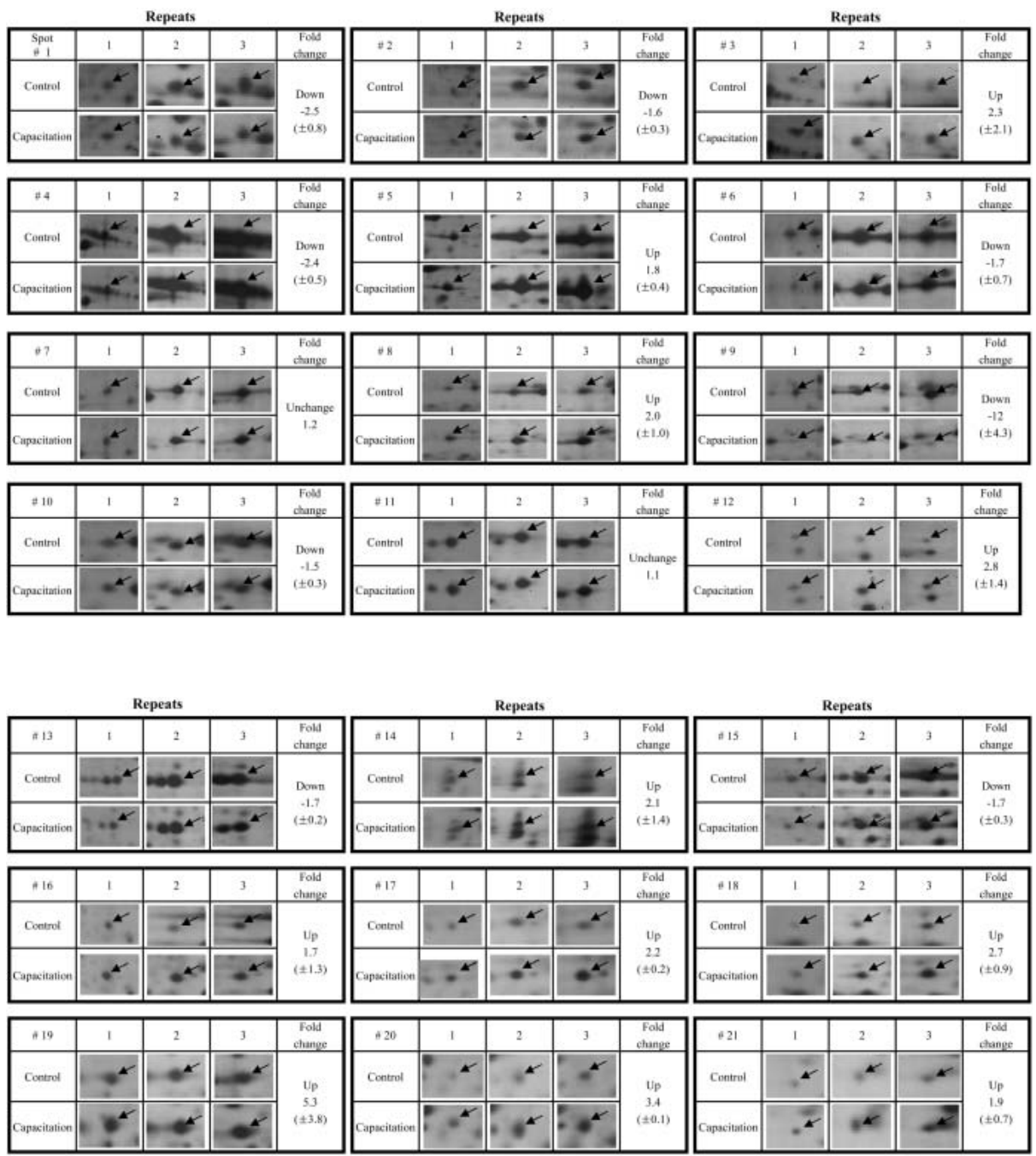

\begin{tabular}{|c|c|c|c|c|c|c|c|c|c|c|c|c|c|c|}
\hline$\pi 22$ & 1 & 2 & 3 & $\begin{array}{l}\text { Fold } \\
\text { changer }\end{array}$ & $\# 23$ & 1 & 2 & 3 & $\begin{array}{l}\text { Fold } \\
\text { changer }\end{array}$ & is 24 & 1 & 2 & 3 & $\begin{array}{l}\text { Fold } \\
\text { change }\end{array}$ \\
\hline Conterol & 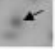 & $*$ & F & \multirow{2}{*}{$\begin{array}{c}U_{p} \\
2.9 \\
( \pm 0.7)\end{array}$} & Control & 2 & F & 2 & \multirow{2}{*}{$\begin{array}{c}U_{p} \\
2.9 \\
( \pm 1.6)\end{array}$} & Contrut & $*$ & & $=4$ & \multirow{2}{*}{$\begin{array}{c}\text { Up } \\
3.0 \\
( \pm 1.0)\end{array}$} \\
\hline recitation & $z^{*}$ & 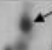 & 4 & & Capsecitation & 2 & 7 & & & Capacitation & 2 & 4 & $e^{2}$ & \\
\hline
\end{tabular}

sFig. 1. Close-up image of differentially expressed proteins of the uncapaciated and capacitated sperm cells. The expression of each protein was significantly upregulated or downregulated in capaciatetd sperm cells compared with uncapacitated sperm cells. Peptides were extracted, their masses were measured by MALDI-TOF-MS and the spectrum was compared with the MS databases. 

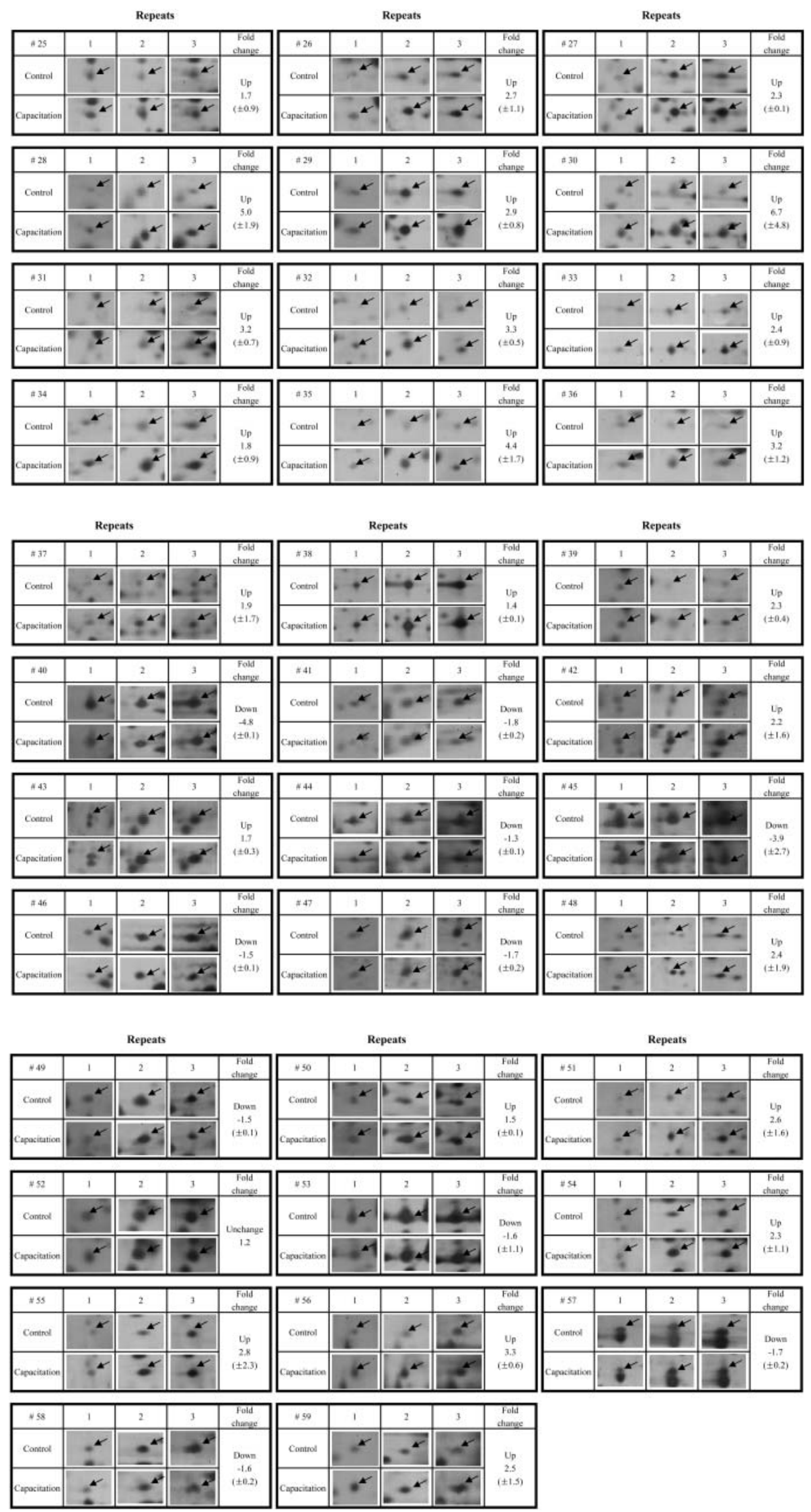

sFig. 1. Continued. 
$\mathbf{A}$

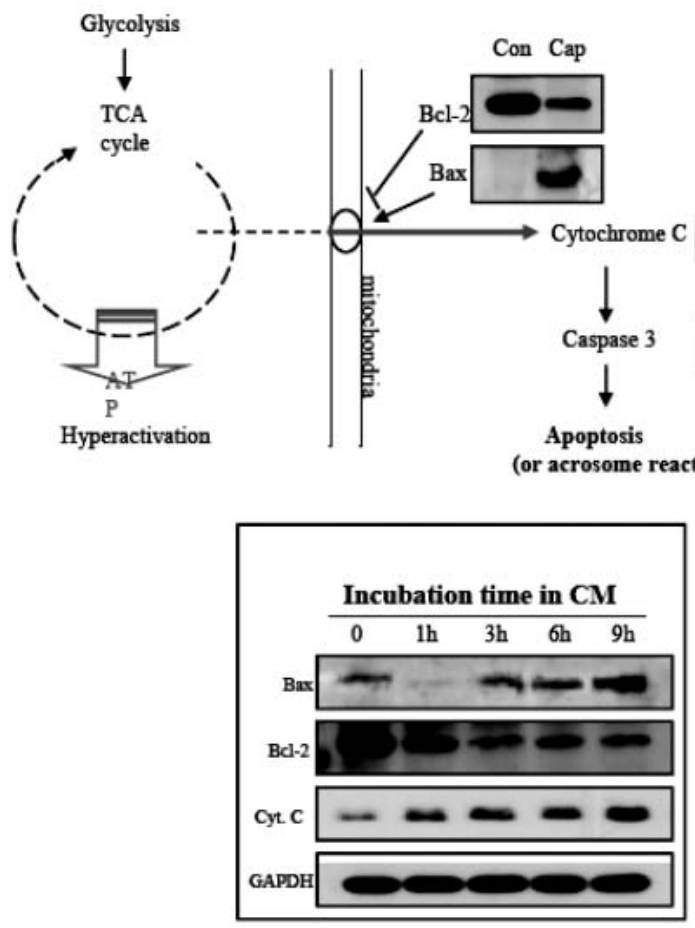

B
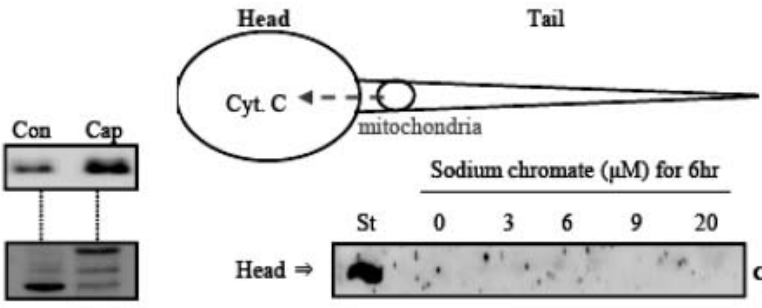

Sodium chromate $(\mu \mathrm{M})$ for $6 \mathrm{hr}$
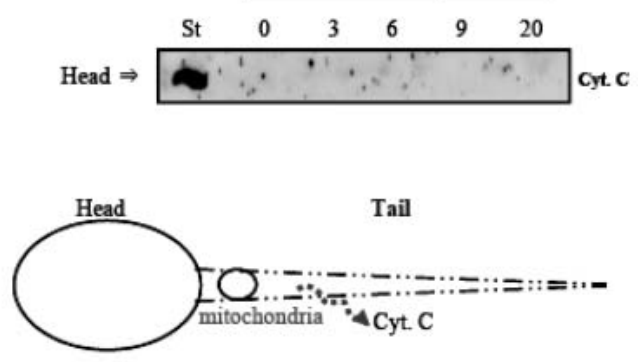

Sodium chromate $(\mu \mathrm{M})$ for $6 \mathrm{hr}$

Tail $\Rightarrow$

sFig. 2. Evaluation of Bcl-2, bax and cytochrome c expression levels during incubation of sperm cells in capacitation medium. Western blot analyses were performed on samples of uncapacitated and capacitated sperm cells $(n=3)$ using antibodies against Bax and Bcl-2. GAPDH was used as a control. The Bcl-2 expression level was decreased, but Bax expression was increased in the capacitated sperm cells as compared with the controls (A). Two possible underlying causes for release of cytochrome $\mathrm{c}$ were explored in a population of sperm heads and tails. We reasoned that if upregulation of cytochrome c could be detected in sperm tails, cytochrome $\mathrm{c}$ expression might be due to release from mitochondira rather than accumulation of cytochrome $\mathrm{c}$. As shown in Fig. 2B, cytochrome c expression in the sperm head was not detected, whereas cytochrome c expression in the sperm tail gradually increased depending on the concentration of sodium chromate, indicating that cytochrome $\mathrm{c}$ was released from the mitochrondia of the sperm tail. The data represents three independent experiments. Con, cap, CM and Cyt.C indicate control sperm cells, capacitated sperm cells, capacitation medium, and cytochrome c, respectively. 